Max-Planck-Institut für demografische Forschung

Max Planck Institute for Demographic Research

Konrad-Zuse-Strasse 1 - D-18057 Rostock - GERMANY

Tel +49 (0) 3812081 - 0; Fax +49 (0) 3812081 - 202;

http://www.demogr.mpg.de

MPIDR WORKING PAPER WP 2012-016

APRIL 2012

\title{
Family systems and welfare provision in Poland-Lithuania: discrepancies and similarities
}

Mikolaj Szoltysek (szoltysek@demogr.mpg.de)

(C) Copyright is held by the authors.

Working papers of the Max Planck Institute for Demographic Research receive only limited review. Views or opinions expressed in working papers are attributable to the authors and do not necessarily reflect those of the Institute. 
Mikołaj Szołtysek

Laboratory of Historical Demography

Max Planck Institute for Demographic Research

Rostock

\section{Family systems and welfare provision in Poland-Lithuania: discrepancies and similarities}

\section{Introduction}

D. Reher in his well known article published in Population and Development Review posited that the diversification of historical family forms at a regional level (for example in Italy) should not cloud the fact there were clearly distinct regions at the scale of the continent ${ }^{1}$. However, his observations converged only partially with the division into regions with different dominant household structures or household formation rules, as proposed earlier by Laslett and Hajnal ${ }^{2}$. In place of this division, Reher introduced the family ties criterion, which is measured through the social reception of familial loyalty, obedience, and authority. This criterion is especially relevant for the point at which adult children leave home and for the protective functions of the family towards its vulnerable members. In Reher's view, what distinguished the family systems of the Mediterranean was the extremely protective and supportive role of the family, as opposed to the weak kinship bonds and emphasis on selfsufficiency that was characteristic of the nuclear households of North-Western Europe, especially England. In proposing this differentiation, Rehar was actually drawing on Laslett's

\footnotetext{
${ }^{1}$ David S. Reher, 'Family ties in Western Europe: persistent contrasts', Population and Development Review, 24:2 (1998), pp. 203-234.

2 John Hajnal, 'Two kinds of preindustrial household formation system', Population and Development Review, 8:3 (1983), pp. 449-494; Peter Laslett, 'Characteristics of the Western family considered over time', Journal of Family History, 2, pp.89-115; Peter Laslett, 'Family and household as work group and kin group: areas of traditional Europe compared', in R. Wall and J. Robin (eds.), Family forms in historic Europe (Cambridge, 1983), pp. 513-563.
} 
earlier assertions that the specificity of inter-generational and kinship relations in England was marked by the absence of a pattern of support and intra-family loyalty stemming from the prevailing system of nuclear families in this region, and the high degree of territorial mobility in response to the conditions of life-cycle service ${ }^{3}$.

Reher's arguments opened a proverbial Pandora's Box, shedding light on the ongoing discussion among historians of the family and society about the broader implications of model approaches to the geography of European family forms, to finally become a catalyst for further debate. According to some researchers, the two disparate models of household formation proposed by Hajnal, the nuclear family model and the joint family model, were supposed to reflect contrasting systems of social security and welfare provision. At the same time, they believed that the models shaped the basic parameters of individual and family life, and in very different ways. In their view, family systems founded on the co-residence of complex kinship groups were characterised by a greater degree of intra-family solidarity (such communities were often described as familistic). At the individual level, this very factor was believed to decrease the negative psycho-social consequences of processes and phenomena related to various stages of life, such as being single, being widowed, or living alone in an "empty nest" ${ }^{4}$. Moreover, it was acknowledged that, in the context of the self-sustainable

\footnotetext{
${ }^{3}$ Peter Laslett, 'Family and collectivity', Sociology and Social Research, $63: 3$ (1979), pp. 432-453; Peter Laslett, 'The significance of the past in the study of ageing', Ageing and Society, 4:4 (1984), p. 380, 384-385; Peter Laslett, 'Family, kinship and collectivity as systems of support in pre-industrial Europe: a consideration of the 'nuclear-hardship' hypothesis', Continuity and Change, 3:2 (1988), pp. 152-175. Similarly: Richard M. Smith, 'The structural dependence of the elderly as a recent development: some skeptical historical thoughts', Ageing and Society, 4:4 (1984), pp. 409-428; Michael Anderson, 'The Impact on the Family Relationships of the Elderly of Changes since Victorian Times in Governmental Income-Maintenance Provision', in E. Shanas and M.B. Sussman (eds.), Family, Bureaucracy, and the Elderly (Durham, 1977), p. 56. Laslett insisted that ,[...] in countries such as England the dominant family patterns not only demanded that relatives in need be refused shelter in a household ... [and] the characteristic attitudes towards kinship ties assumed a clear indifference with regards to the predicament of relatives"; Laslett, Family, kinship and collectivity, pp. 160-161. Also: Peter Laslett, A Fresh Map of Life: The Emergence of the Third Age (London, 1989), pp. 119-121.

${ }^{4}$ Laslett, 'Family, kinship and collectivity'; Roger Schofield, 'Family structure, demographic behaviour, and economic growth', in J. Walter and R. Schofield (eds.), Famine, disease and the social order in early modern society (Cambridge, 1989), pp. 279-304; Mead Cain, 'Welfare institutions in comparative perspective: the fate of the elderly in South Asia and pre-industrial Western Europe', in M. Pelling and R. M. Smith (eds.), Life, Death, and the Elderly: Historical Perspectives (London, 1991), pp. 222-243; Michel Verdon, Rethinking
} 
economy, belonging to a multiple-family system helped to alleviate the acuteness of the experience of successive phases of well-being and poverty ${ }^{5}$.

The critics of this perspective argued that the structure and composition of households constitutes only one of many dimensions of the protective functions of families, and that the analysis of household structure alone should not be used to develop comprehensive approaches to the issue ${ }^{6}$. These scholars were more cautious in addressing the implications of Hajnal's bipolar classification in the field of systems of welfare provision, arguing that ascribing greater efficiency in the provision of protective functions to complex family systems was too mechanistic. Historical and contemporary evidence was called upon to demonstrate that, even in societies in which co-residing with kinsmen, strong kinship ties, and a pro-family orientation were common, there were still cases of plain indifference towards the situations of relatives, examples of intra-familial conflicts, and sharp differences in the quality of life of individual members of residential groups ${ }^{7}$.

The scarcity of source material for Eastern Europe at that time meant that, in most discussions, the region was generally omitted, although the family patterns that were discernible there were still implicitly treated as a peculiar variant of Mediterranean

households: an atomistic perspective on European living arrangements (London, 1998), pp. 87-105. See also Mary Hartman, The household and the making of history. A subversive view of the western past (Cambridge, 2004), in which the author accentuated the adverse effects of complex family systems, especially in terms of gender balance in the social and economic sphere.

5 Peter Czap, 'The perennial multiple family household, Mishino, Russia, 1782-1858', Journal of Family History, 7 (1982), 18; idem, “»A large family: the peasant's greatest wealth «: Serf households in Mishino, Russia, 1814-1858', in Wall and Robin (eds.), Family forms, 143-144.

${ }^{6}$ Piere P. Viazzo and Francesco Zanotelli, 'Welfare as a moral obligation: changing patterns of family support in Italy and the Mediterranean', in H. Grandits (ed.), Family, Kinship and State in Contemporary Europe. Vol.1 The Century of Welfare: Eight Countries (Frankfurt/M 2010), 47-92; Giovanni Levi, 'Family and Kin: A Few Thoughts, Journal of Family History, 15:1 (1990), pp. 570-571.

${ }^{7}$ Peregrine Horden, 'Household Care and Informal Networks: Comparisons and Continuities from Antiquity to the Present', in P. Horden and R.M. Smith (eds.), The Locus of Care: Families, communities, institutions and the provision of welfare since antiquity (London, 1998), pp. 45-51; Sandra Cavallo, 'Family Obligations and Inequalities in Access to Care in Northern Italy seventeenth to eighteenth centuries, in ibidem, pp. 90-110; Zhongwei Zhao, 'Demographic Conditions, Microsimulation, and Family Support for the Elderly: Past, Present, and Future in China', in ibidem, pp. 259-279. 
'familialism" ${ }^{, 8}$ The system of social relations which prevailed in this part of the continent was seen as being based on family-centred, and not on individualistic, principles. Thus it was assumed that, in Eastern Europe, group attitudes had greater significance, with historically conditioned patterns of co-residence and a high degree of family solidarity prevailing among Slavic communities ${ }^{9}$. Recently, these presuppositions have gained yet another dimension owing to the works of the Kinship and Social Security project group which clearly suggest a stronger pro-family orientation among the then-contemporary communities of Eastern Europe in comparison to countries of Western Europe and Scandinavia, supposedly reflected in the greater intensity of contacts with relatives and greater importance of kinship in general in the system of welfare provision ${ }^{10}$.With reference to Eastern Europe it was also provisionally accepted that the patterns observed in Eastern Europe represent a distant historical heritage ${ }^{11}$.

\section{Research questions and source basis}

The survey of literature presented here seems to confirm the benefits of studies on the structure of the household in Eastern European territories, especially in the Polish-Lithuanian lands. In addition to facilitating a revision of prevailing models of the geography of family forms in old Europe, which has already been done several times ${ }^{12}$, these studies provide an

\footnotetext{
${ }^{8}$ Schofield, 'Family structure', pp. 282-285; Laslett, 'Family and household', p. 559. See also Tomáš Sobotka, Postponement of Childbearing and Low Fertility in Europe (Amsterdam, 2004), p. 206.

9 Alan Macfarlane, The origins of English individualism: the family, property and social transition (Oxford, 1978), pp. 18-30; William I. Thomas and Florian Znaniecki, The Polish peasant in Europe and America: monograph of an immigrant group, Vol. 1: Primary-group organization (New York, 1958 [1918]). See also the discussion in Verdon, Rethinking households, pp. 87-105.

${ }^{10}$ Patrick Heady et.al., 'The quantitative background', in P. Heady and P. Schweitzer (eds.), Family, Kinship and state in contemporary Europe, vol. 2. The view from below (Frankfurt/M, 2010), pp. 61-90; Patrick Heady et.al., 'Familism and localism: levels of spatial grouping and their significance for contemporary European kinship', paper presented at the Max Planck Institute for Demographic Studies, April 2009. Cf. a more cautious opinion in Horden, Household care ..., pp. 46-48.

${ }^{11}$ Patrick Heady, 'Introduction: care, kinship and community - the view from below', in Heady and Schweitzer (eds.), Family, Kinship and state, p. 37, 47-48; Patrick Heady et.al., 'Family, kindred and marriage', in P. Heady and M. Kohli (eds.), Family, Kinship and state in contemporary Europe, vol. 3: Perspectives on theory and policy (Frankfurt/M, 2010, p. 42-43, 55; Heady et.al., 'The quantitative background', 87-88. See also Thomas and Znaniecki, The Polish peasant, pp. $87 \mathrm{ff}$.

${ }^{12}$ Mikołaj Szołtysek, 'Life cycle service and family systems in the rural countryside: a lesson from historical east-central Europe', Annales de démographie Historique, 1 (2009), pp. 53-94; idem, 'Three kinds of preindustrial household formation system in historical Eastern Europe: A challenge to spatial patterns of the
} 
opportunity to verify current views on the influence of the manorial system on the shaping of the multi-family character of households in Eastern Europe ${ }^{13}$. Studies into historical coresidence patterns in Poland-Lithuania might also provide us with a better understanding of the relationship between the diversification of family systems of Eastern Europe and a range of other issues, the most important of which are (a) the organisation of work at the level of domestic group (b) the quality of life, and (c) the protective functions of the family.

The present analysis focuses on the latter group of problems. The main focus will be on investigating the question of to what degree the regional diversification of family models in Polish-Lithuanian and Ukrainian lands translates into structural differences in the quality of life of families and individuals, and to what extent this diversification influences discrepancies in the protective functions of the family ${ }^{14}$. Thus, an attempt is made here to answer following crucial research questions: (1) Which of the family systems identified in Polish-Lithuanian lands at the end of the 18th century was most effective in overcoming the cyclical phases of deprivation and impoverishment resulting from the developmental cycle of

European family', History of the Family, 13:3 (2008), pp. 223-257; idem, 'Rethinking Eastern Europe: household formation patterns in the Polish-Lithuanian Commonwealth and European family systems', Continuity and Change, 23:3 (2008), pp. 389-427; idem, 'Central European household and family systems, and the "Hajnal-Mitterauer" line: the parish of Bujakow (18th-19th centuries)', History of the Family, 12:1 (2007), pp. 19-42; Mikołaj Szołtysek and Dariusz Biskup, 'Różnorodność czy tożsamość? Chłopskie gospodarstwo domowe na ziemiach Rzeczypospolitej i Śląska pod koniec XVIII wieku', in C. Kuklo (Ed.), Rodzina $i$ gospodarstwo domowe na ziemiach polskich w XV-XX wieku. Struktury demograficzne, społeczne i gospodarcze (Warszawa, 2008), pp. 363-390.

${ }^{13}$ Mikołaj Szołtysek and Barbara Zuber-Goldstein, 'The effects of manorial institutions on peasant household patterns in late eighteenth-century Eastern Europe: theory, practice, and regional disparities', paper presented at The Annual Conference of the Economic History Society, University of Warwick, UK, April 2009; Mikołaj Szołtysek, 'Female headship, household position, and gendered well-being in peasant societies: evidence from the territories of the historical Kingdom of Poland (18th century)', in M. Durăes et.al. (eds.), The transmission of well-being: gendered marriage strategies and inheritance systems in Europe (17th-20th centuries) (Bern, 2009), pp. 447-486; see also Steven L. Hoch, 'Serfs in Imperial Russia: Demographic Insights', The Journal of Interdisciplinary History, 13:2 (1982), pp. 221-246.

${ }^{14}$ Both parameters - quality of life and the protective functions of the family - are analysed here exclusively in terms of the internal dynamics of the family system. I assume that in the peasant social realities of Eastern Europe at the end of the 18th century, familial and individual quality of life was to a large extent conditioned by the position occupied by the individual within a domestic group. I also profess that through focusing on household or residential communities (dictated by the nature of sources applied in the present analysis), despite obvious limitations, it is possible to sketch the basic framework within which the family's protective functions could be realized. Cf. Szołtysek, 'Female headship', pp. 447-452, and Steven Ruggles, 'Reconsidering the Northwest European Family System', Population and Development Review, 35:2 (2009), pp. 249-273. 
the domestic group? (2) To what degree did the differences between family systems in terms of the structure of households translate into differences in the organisation and composition of labour at the level of residential groups? (3) And, finally, which of the family systems was more 'friendly' towards individuals most threatened by the negative outcomes of specific phases of the individual life cycle, especially elderly people?

Each of these issues will be discussed in depth in a separate section, following a presentation of the methodological and source questions.

$$
* * *
$$

The source basis of the present analysis is provided by a database which includes data on 26,655 peasant households from late-eighteenth-century Poland-Lithuania, belonging to 236 parishes and 900 settlements, and with an overall population of nearly 156,000 persons (the CEURFAMFORM Database). The data were derived from various types of population enumerations listing individuals by residential units, with kinship relationships made transparent within each domestic group. These included primarily the census microdata that between 1790 and 1792 were collected by the Civil-Military Order Commissions on the territories of the Crown of the Kingdom of Poland (including the Ukraine) (49\%). Data from the Lithuanian regions come from the materials of the 5th Russian revision list of 1795 $(37 \%)^{15}$

Various parts of this data collection have already been analyzed, which legitimizes the omission of most methodological and source-related issues related to the database, as well as of a socio-economic characteristic of the investigated communities ${ }^{16}$. Suffice to say, that the

\footnotetext{
15 The remaining $14 \%$ are constituted by listings of a varied provenience, although with a dominance of Status Animarum or Seelenregister known from the German-speaking territories. The collection of census-like microdata applied in this article makes up for a hitherto largest collection of population listings according to households in this part of the continent.

${ }^{16}$ Mikołaj Szołtysek and Konrad Rzemieniecki, 'Between »traditional « collectivity and »modern« individuality: an atomistic perspective on family and household astride the Hajnal's line (Upper Silesia and Great Poland at the end of the $18^{\text {th }}$ century)', Historical Social Research, 30 (2005), pp. 130-70; Szołtysek, 'Three kinds'; idem, 'Rethinking Eastern Europe'; idem, 'Life cycle service'; Mikołaj Szołtysek and Barbara Zuber-Goldstein,
} 
territories under study cover the western and southern fringes of the Polish-Lithuanian Commonwealth (Map 1; regions 1 to 5, 6+7); eastwards into the borderland between presentday Poland, Belarus, and Ukraine (reg. 8); and then even farther east into Belarus, south from Minsk (reg. 11N and $11 \mathrm{~S}$ respectively); and into western Ukraine (reg. 10).

Even though these data are dispersed over considerable space, the "samples" have been quite evenly distributed over major historical regions of the country. The investigated 236 parishes have been grouped into regions, either on the basis of their administrative belonging or geographical proximity. Such regions have been further aggregated into larger groupings using statistical tests and data mining techniques (ANOVA, inter-regional pairwise comparisons according to the Holm-Sidak method, cluster analysis) (Map 2). ${ }^{17}$

The Polish-Lithuanian sample comprises exclusively rural societies engaged in smalland middle-scale farming. An overwhelming majority of the population of all regions were serfs living in personal and hereditary subjugation. The Polish (and Catholic) preponderance over western areas (regions 1-7) was diminishing in favor of large numbers of Belarussians and Ukrainians (mostly Uniates, i.e., Greco-Catholics) in the eastern provinces (regions 8, 10, $11 \mathrm{~N}$, and 11S). This ethnic and religious divide on historical Polish territories was a longlived one, and it retained its spatial validity well into the $1920 \mathrm{~s}$ and $1930 \mathrm{~s}^{18}$.

The EAST 3 cluster, as well as parts of regions 8 and 10 located in nowadays Southern Belarus, Northern Ukraine, and partly in Poland, represent a highly specific areal eccotype known as Polessia. The swamp areas of Polessia known as the Pripyat Marshes has owned

\footnotetext{
'Historical family systems and the great European divide: the invention of the Slavic East', Demográfia: English Edition, 52: 5 (2010), pp. 5-47.

${ }^{17}$ The description of these methods is included in Szołtysek and Biskup, Różnorodność czy tożsamość, p. 373375, 380, 382, 384, as well as in, Mikołaj Szołtysek and Dariusz Biskup, 'Diversity, variation and the time-space conundrum: family forms in Eastern Europe further explored', paper presented at a seminar organized by the Cambridge Group for the History of Population and Social Structure, University of Cambridge, February 2008.

${ }^{18}$ Bogumił Szady, Geografia struktur religijnych $i$ wyznaniowych $w$ Koronie $w$ II połowie XVIII w. (Lublin, 2010).
} 
their peculiarity to harsh ecological conditions, socioeconomic backwardness and historically grounded cultural distinction ${ }^{19}$.

Table 1 presents a summary of the basic values of variables describing the singled-out family systems. The regions included in the western cluster (WEST) were characterised by a very high share of households of a nuclear structure (nearly $80 \%$ ), and by the moderate size of households ${ }^{20}$. Nearly one-fifth of the total number of households were either of an extended or complex nature, but only one in 10 households contained more than one conjugal-familial unit. The share of co-resident kin in the populations of the macro-region was very small, amounting to $5 \%$. Of much greater significance were the life-cycle servants and lodgers: the share of each of these categories in the total population of the region reached $12 \%$, and, by the end of the 18th century, the presence of household servants and inmates in peasant households (in at least every third household on average) had become a well-established pattern in the western territories ${ }^{21}$. According to previous research, the family formation system in the territories of the western cluster was neolocal, with only the periodic co-residence of two generations, as was characteristic of the family formation model in regions dominated by socalled stem families ${ }^{22}$.

\footnotetext{
${ }^{19}$ See, for example, R.A. French, 'Field patterns and the three-field system: the case of sixteenth-century Lithuania', Transactions of the Institute of British Geographers, 48 (1969), pp. 121-134; idem, 'The three-field system of sixteenth-century Lithuania', Agricultural History Review, 18 (1970), pp. 106-125; W.K. Bondarczyk et. al. (eds.), Obszczestwennyj, semiejnyj byt i duchownaja kultura nasielenija Polessia (Mensk, 1987); Józef Obrębski, Polesie. Studia etnosocjologiczne (Warszawa, 2007).

${ }^{20}$ Incompleteness of the registration of youngest generations occurred rather unevenly among the included parishes and estates; apparently, it wasn't either a widespread phenomenon in any of the macro-regions. The average percentage of children and youth between the ages of $0-14$ in the total populations of the 225 parishes for which the listings provided the ages of inmates, amounted to $38.4 \%$ which does not differ drastically from other scholars' proposition of a ca. 40-percent-level suggesting a relative adequacy of registration (Irena Gieysztorowa, Wstęp do demografii staropolskiej (Warszawa, 1976), p. 100-101, 133. As in the majority of listings from the pre-statistical era, age heaping was very much pronounced in the materials applied here, with an even greater intensity in the eastern regions. The Whipple Index (for both sexes combined) amounted to, respectively: 183 for the cluster WEST, 203 for EAST 1, 313 for EAST 2 and 312 for EAST 3; the valueas are comparable with listing data for contemporary developing countries. See more in Mikołaj Szołtysek, "”A sheer jungle of uncertainties and traps": uses and misuses of premodern census microdata', paper presented at the Seminar of Economic History, University of Tübingen, Department of Economics (Germany), June 2011.

${ }^{21}$ In more detail: Szołtysek, 'Life cycle service'.

${ }^{22}$ Szołtysek, 'Central European household'; idem, 'Three kinds'.
} 
In the basic parameters of its family systems, the EAST1 cluster exhibited all of the features of a typical transitional territory. A significantly greater number of families extending beyond the primary nucleus were found here. There was a nearly perfect numerical balance of simple and complex families (50\% and $47 \%$, respectively), but the latter were formed more frequently through the co-residence within one household of several familial units, often married brothers with their families. Whereas the indicators of family system complexity in the EAST 1 cluster increased sharply, the share of servants and lodgers was distinctly lower than the levels observed in western Poland. In those regions, only every $10^{\text {th }}$ household hired servant, and only every $13^{\text {th }}$ took in other unrelated co-residents. Having much in common with the family systems described in the literature as joint families, the family model that prevailed in the territories included in this grouping exhibited many 'hybrid' features, especially traces of co-residing servants with a demographic profile not unlike that of the lifecycle servants from the western regions of the continent ${ }^{23}$.

The tendencies observed in the parishes of the EAST1 cluster were much more pronounced in the Polessian part of Belarus (EAST 3). With only a slightly larger average household, the residential communities in this region were characterised by a clear predominance of extended and complex households (over $65 \%$ of the total), among which multiple households constituted a clear majority (over $80 \%$ of households were shared by relatives). At the same time, a clear preference for co-residing with relatives meant that $74 \%$ of all conjugal-familial units resided in households with a multiple structure (Laslett's $5 \mathrm{a}-5 \mathrm{f}$ types), and only $20 \%$ lived in nuclear households, a share nearly four times smaller than in the Polish western regions and two times smaller than in the transitional territory discussed above. What further distinguished this region was the specificity of the co-residence pattern of

\footnotetext{
${ }^{23}$ Szołtysek, 'Life cycle service'; see also: Mikołaj Szołtysek, 'In search for place: Eastern Europe, transition cultural zone and serfdom. Some theses on hybrid family systems', paper presented at the $7^{\text {th }}$ European Social Science History Conference, Lisbon, February 26 - March 1, 2008.
} 
related persons, which was to a considerable extent realised through the zadruga-like forms; i.e., married brothers and other lateral relatives managing the household conjointly, under one $\operatorname{roof}^{24}$. The picture of family systems in these lands is complemented by an almost total lack of household service workers and other unrelated co-residents ${ }^{25}$.

The differences between the family systems in the Polish-Lithuanian lands outlined here offer considerable opportunities for further investigation of the influence of family structures on other aspects of demographic and social behaviours ${ }^{26}$.

\section{The family system and the developmental cycle of domestic group}

First, the functioning of the three major family systems was analysed from the perspective of the theory of the household development cycle ${ }^{27}$. It has been widely recognised, including in the Polish literature, that households undergo several development cycles, from expansion, to dispersion, and finally to division. Much less frequently examined are the socio-economic consequences of these processes and their diversification based on the local familydemographic specificity. In particular, little is known about how in demographic systems with distinct mechanisms of family formation and co-residence strategies the economic efficiency

\footnotetext{
${ }^{24}$ Family of this type occurred in a little over than $20 \%$ of all multiple-family households on Belarusian Polessie.

${ }^{25}$ The phenomenon is not an artifact triggered by the specificty of the Russian revision listing on the investigated regions. Unlike on other territories of the then Russian Empire, on Lithuanian lands the 5th Soul Revision in most cases did register servants (Szołtysek, 'Three kinds', pp. 6-7). Observation made by Żabko-Potopowicz on the relative popularization of the institution of service on Lithuanian lands at the end of the 18th century does not negate the present assumptions as they refer mostly to the northern parts of the Grand Duchy of Lithuania; see Antoni Żabko-Potopowicz, Praca najemna i najemnik $w$ rolnictwie $w$ Wielkim Księstwie Litewskim $w$ wieku osiemnastym na tle ewolucji stosunków w rolnictwie (Warszawa, 1929), pp. 61-62, 111, 162-174, 181.

${ }^{26}$ The EAST 2 cluster, with the prevalence of small and most frequently nuclear families, constitutes an anomaly with regards both to more complex family formations noted in the Zytomierski district, and to observations made by some authors in terms of family relationships characteristic of the 19th century Bukovina and Pokucie. See: Roman Rozdolski, 'Die Ostgalizische Dorfgemeinschaft und ihre Aufloesung', Vierteljahrschrift fuer Sozialund Wirtschaftsgeschichte, 41:2 (1954), pp. 97-145; Stella Hryniuk, Peasants with promise: Ukrainians in southeastern Galicia 1880-1900 (Edmonton, 1991), pp. 22-24. The issue calls for further investigation, especially seeing the scant sizes of samples from the discussed territories. Due to small number of cases involved, this region had to be excluded from many calculations presented in this essay.

27 Jack Goody (ed.), The Developmental Cycle in Domestic Groups (New York, 1958); Lutz K. Berkner, 'The stem family and the developmental cycle of the peasant household: an eighteenth-century Austrian example', The American Historical Review, 77:2, pp. 398-418; Eugene A. Hammel, 'Chayanov revisited: A model for the economics of complex kin units', Proceedings of the National Academy of Sciences of the United States of America, 102: 19 (2005), 7043-7046.
} 
of the household and its feeding capacities change along with the progression of the development cycle. A. V. Chayanov has analysed these issues in reference to Russian villages of the end of the 19th century, but his concepts retain a general heuristic value for the examination of the issues explored here ${ }^{28}$.

In order to answer the question posed, three research procedures were applied. First, the households in the three clusters were divided according to the ages of the household heads, which means that subsequent age groups were treated as synthetic cohorts ${ }^{29}$. For each of these 'cohorts' in each of the three different family systems, the ratio of demographic dependency was calculated, defined as the proportion of persons aged 0-12 and 60 and older, to persons aged $13-59^{30}$. The calculations were conducted separately for core families (or with the inclusion of relatives) and households (i.e., core families according to the above definition, along with household servants, but without lodgers). In the second stage, with the

\footnotetext{
${ }^{28}$ Alexander V. Chayanov, A. V. Chayanov on the Theory of Peasant Economy, ed. by D. Thorner, B. Kerblay and R. E. F. Smith (Homewood, 1966). The present reference to Chayanov's model is of a general nature and does not aspire to its full application to the historic reality under investigation here. Chayanov viewed peasant family as a team of 'consumers' and 'producers,' thinking of it as a predominantly nuclear family relying solely on its own labour force (Chayanov, A. V. Chayanov on the Theory, p. 54). The standard of living of such a collective depended first and foremost on the numerical relation between both groups of inmates, and the factor which determined the dynamics of this relation was the family's biological cycle. If Chayanov's biological definition of the family is substituted by a view of it as a economic community of co-resident related and nonrelated persons (towards which we, for obvious reasons, incline), then it has to be acknowledged that it is the household's developmental cycle and not the narrowly-understood reproductive cycle of a conjugal-family unit, that was crucial for the efficiency of peasant economy. Such an approach allows for a more realistic grip on the dynamics of the changeability of the c/p ratios, through acknowledging, apart from the 'supply' of the offspring and its growing up, the extension of the household's production powers through the incorporation of relatives or hiring wage labour. Both of these elements are of a prime significance for the understanding of households' economic efficiency on the investigated lands. Cf. Similar remarks by Hammel, 'Chayanov revisited', and Stephen P. Reyna, 'The Extending Strategy: Regulation of the Household Dependency Ratio', Journal of Anthropological Research, 32:2 (1976), pp. 182-198.

${ }^{29}$ This is a popular method applied in historical-demographic research in case of lack of listing materials in a long-term perspective. It entails that family characteristic of various age groups in a survey context (position within a household or, as discussed here, managing a household of a determined structure) represents an 'average' experience of an actual cohort when approached dynamically, with the assumption that a given group of people would be subjected to a long-term investigation.

${ }^{30}$ Demographic dependency ratio is a conventional measurement applied in demography to determine the ratio of pre- and post- production populations to production populations; see: Henry S. Shryock, The methods and materials of demography, New York 1976, p. 133-134; Donald T. Rowland, Demographic methods and concepts (Oxford, 2003), pp. 86, 88-91. Dependency ratio is a synthetic measure determined solely on the basis of age data, and not in relation to mutual proportions of working people and those remaining inactive. This reservation acquires particular significance in the studies of populations in which the practices of child labour and hiring under-age laborers occur.
} 
use of similar procedures, the ratio of 'producers' to 'consumers' was calculated, with a slight modification of Chayanov's original postulates ${ }^{31}$. For each of the age groups of household heads, the numerical ratio of both of these categories of household members was determined, including data on the ages of the heads and their children, the co-residing relatives with their own families, and the servants. The third stage consisted of calculating the ratio of demographic dependency separately for nuclear, extended, and multiple households within the frames of each of the three household systems.

The analysis of the ratios of demographic dependency in the three clusters revealed trends closely resembling those predicted by Chayanov's model (Figure 1). In all of the groupings, the households' production dependency, resultant from their decreasing production capacities, grew gradually, starting with the youngest household heads, and reaching peak values among men in their thirties; that is, assuming men's average age at marriage was around $23-26$, in the $15^{\text {th }}-17$ th year of the procreative career of an ordinary peasant family ${ }^{32}$. In older 'cohorts,' the curve of the trend falls as the children grow up and enter the age of

\footnotetext{
${ }^{31}$ For Chayanov, the starting point for the model of the family cycle was a lone couple of young spouses. The $\mathrm{c} / \mathrm{p}$ ratio in such a family changes with the births of consecutive children and increases until the moment in which the first child reaches his/her productive age (around the age of 13). Owing to this, in the family developmental cycle the heads' couple experiences a long-term deterioration of standard of living the peak of which falls on the 12th and 13th year of their marriage. As the other children reach maturity, each 'producer's' burden becomes lessened because the number of dependent persons decreases. Children are treated as rightful producers only after they turn 20, and above this border the consumptive and productive value of both genders is constant and amounts to 1 for men and 0.8 for women. The present analysis proposes a more dynamic approach to the process of balancing contribution of labour and share in consumption, both among the younger and older generations. It purports that among children the relationship between production and consumption becomes gradually equated already between the age of 12 and 19 (for female offspring between 12 and 17), and then assumes values identical as those for adults devised by Chayanov. Beginning with the age of 50, the labour contribution and consumption balance starts to falter as the productive powers weaken owing to the ageing process. The process occurs faster among women than men: the former are treated as 'half-producers' already at the age of 57, the former - of 60. The proposed modifications appear more realistic than Chayanov's claims. They find justification in the significant proportion of under-15 years old servants found in the communities under study. Model identical to the one proposed here was successfully applied previously for the analysis of family strategies of peasants from central lands of the Minsk Province in the years 1762 - 1858; see Viachaslau Nosevich, 'Modiel żizniennogo cikla krestjanskago dworochaziaistwa', Informatsionnȳ̌ byulleten' Assotsiatsii «Istoriya i komp'yuter», 30 (2002), pp. 202-205.

${ }^{32}$ Based on: Michał Kopczyński, Studia nad rodzina chłopska w Koronie $w$ XVII-XVIII wieku (Warszawa, 1998), p. 141-142; Bogdan Puczyński, 'Ludność Brzeżan i okolicy w XVII i XVIII wieku. Część 2', Przeszłość Demograficzna Polski, 5 (1972), p. 23-25; Konrad Rzemieniecki, Ludność rzymskokatolickich parafii monasterzyskiej i petlikowskiej w XVIII wieku (archidiecezja lwowska), manuscript of a doctoral dissertation, Institute of History, University of Wroclaw, 2006.
} 
production, reaching the lowest values among fifty-year-olds. Within the group of oldest heads, a decrease in production efficiency again appears, but is this time more drastic owing to the emancipation of offspring and the heads' entry into the 'empty nest' phase (in the WEST), or the separation of multiple households into individual units (in the eastern clusters $)^{33}$.

A comparison of family groups from the western cluster (FDR), with family systems with a considerable share of co-residing relatives, demonstrates that, throughout almost the entire development cycle of a household except for the youngest heads, the relative demographic dependency of the former was distinctly heavier. Although in regions of more complex family structures the numerical ratio of pre- and post-production populations to those in the production stage underwent very similar fluctuations, the composition of these households enabled their members to lessen the negative implications of the development cycle by over $10 \%$ relative to western regions, and, among the oldest cohorts, by as much as $20 \%$.

However, the inclusion of hired labour (HDR) in the western regions decisively changes this situation. The use of hired labour - i.e., employing wage labourers during periods when the family was less productive (such as at the beginning of the family's procreative career and after the emancipation of offspring) - helped to relieve the dependency of family households on average by $10 \%$ relative to previous calculations, and, at the peak of productive deprivation (cohorts aged $33-37$ and $63+$ ), by as much as $20 \%$. As a result, the degree of demographic dependency in a family system dominated by nuclear households relying on hired labour, is equated with the values for eastern regions, and, in the most

\footnotetext{
33 Viachaslau Nosevich, 'The multiple-family household: relic of a patriarchal past or more recent phenomenon?', paper presented at a seminar organized by the Cambridge Group for the History of Population and Social Structure, August 2007; Szołtysek, 'Three kinds', p.26.
} 
economically endangered cohorts, it assumes values below the average for complex family systems.

Family systems characterised by the highest degree of complexity of family households (Polessia in the EAST 3 cluster) did not show a substantially greater degree of flexibility than the 'transitional' family system from the Minsk province (EAST 1); moreover, in the youngest and oldest cohorts, the dependency of family households was even greater.

Figure 2, which graphically depicts the values of the Chayanov's ratio for separate cohorts of household heads, confirms the observations presented above $\mathrm{e}^{34}$. If the share of hired labourers in the western regions is taken into consideration, then the differences in the $\mathrm{c} / \mathrm{p}$ ratios between the clusters turn out to be only minor. It should be noted, however, that the households from the grouping WEST were generally less burdened by non-productive generations during the most arduous stages of the development cycle. The older cohorts exhibit a replication of the pattern from figure 1, though in a slightly more pronounced form: the highest values of the c/p ratio were found in the most complex family system (EAST 3) and the lowest in the transitional region. Meanwhile, in the western regions, the curve assumes mediate values. In all of the clusters, the demographic dependency was shown to increase sharply among older household heads, exceeding levels from the period of the full reproductive career.

Table 2 presents the values of demographic dependency ratio for nuclear, extended, and multiple households within the frames of each of the three family systems. Again, what is most striking is the clearly compensatory character of employing wage labourers among households in the west. For households of all categories, hiring servant was a very profitable

\footnotetext{
${ }^{34}$ It concerns the comparison of eastern and western households in their full composition, that is, with the inclusion of servants but excluding lodgers. More significant than the ratios' absolute values is here their relative value, as in comparisons of the demographic dependency. Nosevich, referring to Belarusian material, as the critical level of Chayanov's ratio understood values between 1.32 and 1.36. Nosevich, 'The multiple-family'.
} 
practice which led to much more favourable proportions of pre- and post-production populations in relation to those in the economically active age range. Hiring servants proved to have a particularly strong compensatory effect in extended households, usually consisting of a couple of young heads and one parent. This confirms the assumptions of earlier literature about the adverse balance of productive powers in the so-called wycugowe households, in which the presence of a widowed parent (often regulated by leave-taking contracts) created significant burden for the nuclear family of the earlier generation ${ }^{35}$. The demographic dependency in extended households relative to nuclear ones was only compensated with the hire of servants.

Data from the eastern territories do not seem to confirm the hypothesis that domestic groups with a greater share of co-residing relatives had a greater level of productive efficiency. A comparison of the three clusters shows a clear and unfavourable progression of the demographic dependency of households while advancing from less to more complex family systems. In regions with a higher incidence of complex forms of co-residence, the difference in the values of the dependency ratios between nuclear and multiple households was much more pronounced than in western and central Poland. Households in the eastern regions, which lacked the institution of life-cycle service, turned out to be much more burdened by non-productive generations than their equivalents in Polish western lands. Life in nuclear households in these territories could well signify a serious threat to the standard of living of their members; thus, it comes as no surprise that these forms were only a transitional phase in the development cycle of families ${ }^{36}$.

\footnotetext{
${ }^{35}$ Hermann Rebel, 'Peasant Stem Families in Early Modern Austria: Life Plans, status tactics, and the grid of inheritance', Social Science History, 2:3 (1978), pp. 255-291.

${ }^{36}$ Nosevich, 'The multiple-family'; Szołtysek, 'Three kinds', p. 26. This is how, during Obrębski's 1920s expeditions, one of his interlocutors explained the occurrence of 'grand families' in Polessia in the earlier periods: 'If a family is small, then it cannot manage such a dispersed land. When it's time to sow or reap, then there is no one to be left home. That is why they lived in huge families - some members went to reap, while hostesses remained at home to run the household'; see Obrębski, Polesie, p. 139.
} 


\section{The family system and the size and structure distribution of household work groups}

In the second stage of the present investigation, the composition and profile of men's labour in the three family systems were analysed. Table 3 presents the distribution of households in terms of the number of men aged 14-60, with a division into territorial clusters ${ }^{37}$.

Despite the differences in the characteristics of the three family systems, in each of these systems approximately three-quarters of all households on average included two men of productive ages. The total average number of men between the ages of 14 and 60 did not differ significantly between the systems. In the western region and in the transitional zone, the number was nearly identical, and amounted to around 1.7 men in each household; in the Polessian territories in Belarus, the average was around two men per household. The slightly higher average number of working men found for the EAST 3 region resulted from the greater share of households with two or three men of productive ages.

However, the general similarities between the numerical structures of men's labour force concealed significant differences in composition (figure 3). In all investigated regions, a dominant phenomenon was the reliance for men's labour force on family resources, recruiting from household heads and their sons. In all of the groupings, over three-quarters of male workers were drawn from this category. What sharply differentiated the family systems studied here was the degree to which co-residing relatives from beyond the biological family and hired strangers were involved in the productive activity of a household. The western regions of the former Crown represented a mixed model, in which as much as one-quarter of the labour force was made up of unrelated individuals accepted into the community of the household in the form of servants. Owing to the generally low share of relatives in the

\footnotetext{
${ }^{37}$ Within this scope, a discussion of methodology is provided by Andrejs Plakans, 'Peasant farmsteads and households in the Baltic littoral, 1797', Comparative Studies in Society and History, 17 (1975), pp. 18-19. Acknowledging the comparisons of Polish-Lithuanian material with studies from other regions, different age divisions than those from figures 1 and 2 were used.
} 
household groups in the western regions, these individuals constituted only $4 \%$ of the total labour force in the local households.

The situation was radically different in the East. In the transitional zone - i.e., in Red Ruthenia, in northern Ukraine, and in central Belarus (the EAST 1 cluster) - the share of more distant relatives in the total male labour force nearly quadrupled, whereas the proportion of hired wage labourers fell to the level of the share of relatives in the western territories $(4 \%)$. Data from Polessia (EAST 3) show a further progression in the direction of productionconsumption units made up almost exclusively of family-kin. In the EAST 3 cluster, the share of unrelated persons among all male workers did not exceed $1 \%$. Slightly over one-quarter of all men of productive ages were recruited from distant relatives co-residing in the household. Their share of the additional labour force on the southern territories of Belarus almost completely matched the share in the western households of positions occupied by servants, who were usually employed and were unrelated to the host's family.

These differences suggest that there were two distinct strategies for selecting household members and organising domestic labour which seem closely related to the locally dominant rules of household formation, rates of home-leaving, and other elements of individual life cycles. In areas where nuclear families and neo-local rules of household formation prevailed, the isolation of the nuclear family from wider kin during the family's procreative career, and later on, the high rate of adult children leaving home, were compensated for through the inclusion of minor and juvenile hired labourers in the production-consumption activities of the domestic group. In the eastern regions, the extension of a household's productive potential was achieved mostly through the consolidation of the kin component within the context of the residential community; that is, through the delay of the adolescent child's home-leaving (especially of the sons), patri-local marriages of the male 
offspring, or the co-residence of married brothers until their families reached a point in the demographic development cycle that presented favourable conditions for their separation.

\section{The family system and the predicament of the elderly}

Studies on the historical family have devoted special attention to the predicament of the elderly $^{38}$. Scholars investigating this issue with the use of mass sources of a demographic character have particularly stressed the significance of co-residence patterns among elderly populations. The answers to the questions of where, with whom, and under what conditions older people would spend the autumn of their lives depended on the strength of family bonds, family loyalty, and the supportive and protective functions of the family, all of which constituted important characteristics of a given social system ${ }^{39}$.

These questions also captured the attention of 19th-century observers of peasant life. Kolberg, in a collection of ethnographic materials from the territory of Kujavia in the northcentral part of Poland (Kolberg 1867; region 3 in our collection), thus described intergenerational relations as follows: "The young have much respect for the old. A farmhand, even if married, will uncover his head before a venerable household head, bowing down to his knees; still, however, that does not prevent the young generations, unwilling to feed the oldest members of their families for no measurable goods in return, from sending the greybeards out to beg, as they could no longer contribute to the family production and were only able to

\footnotetext{
${ }^{38}$ See e.g.: David I. Kertzer and Peter Laslett (eds.), Aging in the Past: Demography, Society, and Old Age (Berkeley-Los Angeles, 1995); Peter Stearns (ed.), Old age in preindustrial society (New York, 1982); Tamara $\mathrm{K}$. Hareven (ed.), Aging and generational relations. Life coure and cross-cultural perspectives (New York, 1996).

${ }^{39}$ Richard Wall, 'Elderly Persons and Members of Their Households in England and Wales from Preindustrial Times to the Present', in Kertzer and Laslett, Aging in the Past, pp. 81-106; Rudolf Andorka, 'Household systems and the lives of the old in eighteenth- and nineteenth-century Hungary', in Kertzer and Laslett, Aging in the Past, p. 129; Susannah Ottaway, The Old Woman's Home in Eighteenth-Century England, in Lynn Botelho and Pat Thane (eds.), Women and Aging in British Society since 1500 (Harlow, 2001), pp. 111-138.
} 
nurse grandchildren. The practice, though, is considered natural order of things and does not bring discredit to either side." 40

There is considerable evidence that, in Belarusian and Ukrainian lands, intergenerational relations had a radically different nature. Dovnar-Zapolsky noted that, at the end of the 19th century, in grand multiple families from Polessia "the will of the father, the mother or old grandfather - that is, of the elder of the house - is sacred and recognised by each and every member of the family." material collected in the interwar period by Obrębski, who defined the family relationships among Poleshuks as "patrolatry" (divine worship of the father) ${ }^{42}$. This was not, however, an "absolute patriarchy," and, in extreme cases, the power relationships between the father and son could deviate entirely from this model, leading to acts of violence against the representative of the older generation ${ }^{43}$. In Polessia, as Obrębski remarked, this cult of the father generally also translated into a widely accepted notion of exceptionality and superiority of the social status of the elderly ${ }^{44}$.

Goško painted a similar picture on the basis of entries in village court rolls from eastern Galicia (partly overlapping with our region 10). Referring to material from the 17th and 18th centuries, he recalled numerous examples of the community upholding the position and authority of parental power ${ }^{45}$. At the beginning of the 19th century, the Lviv ethnographer and historian Ł. Lubicz-Czerwiński, now long forgotten, noted the existence of the institution

\footnotetext{
${ }^{40}$ Oskar Kolberg, Lud. Jego zwyczaje, sposób życia, mowa, podania, przysłowia, obrzędy, gusta, zabawy, pieśni, muzyka i tańce. Serya III. Kujawy. Czesść pierwsza (Warszawa, 1867).

${ }^{41}$ M. Dovnar-Zapolsky, 'Oczierki siemiejnago obycznago prawa krestjan Minskoj gubierni, Vol. 1', in M. Dovnar-Zapolsky, Etnografia, obycznaje prawo, statistika, bieloruskaja pismiennost (Kiev, 1909 [1897]), p. 10.

42 Obrębski, Polesie, p. 167.

43 Ibid.

${ }^{44}$ Ibid., 150-151.

${ }^{45}$ Yuriy Goško, Zwyczajewie prawo nasielennia ukrainskich Karpat ta prikarpattia XIV-XIX st. (Lwiw, 1999), pp. 237-242.
} 
of "seers" in Sub-Carpathia (south from region 10), which consisted of all men above age 60 who, because they performed a variety of community functions, were held in high esteem ${ }^{46}$.

Thus, it is particularly tempting to investigate the extent to which the discrepancies stemming from very random studies of ethnographic literature are reflected in factual material from the end of the 18th century. A survey of these issues commences with the analysis of the structure of households managed by elderly people (figures $4-5)^{47}$.

These figures clearly show the drastic inter-regional differences in the distribution of older household heads among different types of households. In the central and western Crown lands and in Silesia (WEST), 75\% of all households headed by men above the age of 63 were of a nuclear type, and only $14 \%$ of them assumed complex family forms (figure 6). An observation of the changes in the structure of households among all age groups of their heads (not tabulated) indicates that a high percentage of simple families among older people was not a factor specific for this phase of the family developmental cycle, but, rather, that it characterised the cycle's entire progress, with the exclusion of the youngest generations. Only from the age of 50 onwards, the percentage of heads managing nuclear households, which up until this point remained at a constant level of about $77 \%-83 \%$, began to decrease. Meanwhile, the share of extended families among older heads grew progressively once moving from the age groups $60+, 70+$, and even $80+$ (to $20 \%$ ). Nevertheless, following the thread of Laslett's reasoning, we would still have to assume that, among the elderly populations in these territories, the percentage of households threatened by the lack of support from co-residing relatives (that is, exposed to the effects of nuclear hardship) remained very

\footnotetext{
${ }^{46}$ Ignacy Lubicz-Czerwiński, Okolica Zadniestrska między Stryjem a Łomnica (Lwów, 1811), p. 160-161.

${ }^{47}$ Recent demography places the borderline of old age at 60 years. Differently in Wall, 'Elderly Persons', where the author defines this threshold as the age of 65. Further in the present analysis we intermittently use two age thresholds: 60 or 63 years. Application of the 63 age borderline stemmed from grouping individuals into age categories so that age points of greatest age heaping determined the middle of the range (Cf. David V. Herlihy and Christiane Klapisch-Zuber, Tuscans and their Families: A Study of the Florentine Catasto of 1427 (Yale, 1985), pp. 170-179, 182-183). In the last table of the essay a broader age range was used $(60+)$, because the main intention was to ensure a possibly widest numerical base for meticulous calculations included there.
} 
high $^{48}$. However, more detailed data on the composition of nuclear households headed by married men aged 63+ (not included in the table) confirm these assumptions only partially. It turns out that up to $70 \%$ of heads from this group lived with unmarried offspring. Although nearly one-third of elderly men in this category lived in households in which their children had already left the family home, only $15 \%$ of household heads lived with only their wives, but no offspring ${ }^{49}$.

In the transitional zone (EAST 1), the percentage of heads managing households inhabited exclusively by immediate family was prone to more pronounced fluctuations (not tabulated). Following the peak among age cohorts $38-42$ and $43-47$, when over $65 \%$ of all heads managed simple family units, the share of these households decreased steadily, and among heads of aged 63 and older in figure 6 , a total reversal of the previous proportions took place (with $62.2 \%$ of heads managing multiple-family households, and only $23.8 \%$ managing nuclear households in this group).

The deviation from the western model was even more extreme in the Polish territories, where the majority of household heads of advanced age managed multiple-family households (over $80 \%$ ). The marked increase in this age group $-114 \%$ relative to levels among 20 - and 30-year-old heads - points to a distinct striving for the accumulation of labour during the late stages of the family developmental cycle. The patriarchal Belarussian family extended through the marriages of their male members, so that after the death of the head it could break down into individual households of adult sons, which with time underwent the stages of expansion and separation ${ }^{50}$.

\footnotetext{
${ }^{48}$ Laslett, 'Family, kinship and collectivity'.

${ }^{49}$ Twice as much held in their households either servants or lodgers. The share of both of these categories in the productive activity of a farmstead, as well as loyalty bonds with the heads' family, were not identical.

${ }_{50}$ Nosevich, 'The multiple-family'; Szołtysek, 'Three kinds', p. 26; Obrębski, Polesie, p. 146-147. On eastern regions the mean size of a domestic group increased substantially with the head's advancement in age, and in the group of oldest heads reached 6.5 person per farmstead in the 'transitional' zone, and 7.6 person in Polessia (EAST 3). In the western cluster the size of a farmstead diminished with the head's advancement in age.
} 
Similar calculations conducted for the eastern cluster reveal that the empty nest syndrome was virtually non-existent in these groupings. In the transitional zone (EAST 1), only $4 \%$ of all households in this age group had no co-residing offspring, and just 19 married couples out of the 1,025 who headed individual households lived alone. Similarly faint indications of the existence of the post-parental phase appeared in the Polessian region of cluster EAST 3.

The scarce data available for the territories under study on the relatively rare phenomenon of female headship ${ }^{51}$ do not provide sufficiently convincing evidence on the inter-regional differences. Nevertheless, the data presented in figure 5 are immensely telling, even if they indicate only a certain range of possibilities, rather than distinct tendencies. What is most striking in the eastern regions is the considerably reduced significance - or even a total absence - of two phenomena that clearly existed among women in the west: i.e., managing a simple household (a widow with children) and managing it single-handedly. Although the impact of these patterns compared with all of the phenomena noted in the investigated territories was rather faint, the very occurrence of those differences exacerbates the previously noted discrepancies between the regions, especially given that the femaleheaded household in eastern regions, like those headed by men, showed a strong tendency towards maintaining a multiple-family structure.

Further on, the population of men and women of advanced ages was divided according to the positions they occupied within a household (figures 6-7).

Particularly noticeable in the western cluster is the markedly smaller share of household heads relative to eastern regions. Whereas in complex family systems, the function of the household head was strictly held by older generations, in the west, social senility -

\footnotetext{
${ }^{51}$ Szołtysek, 'Female headship'.
} 
which was understood as the point at which the household management was bequeathed to the successors (not necessarily related) - commenced earlier ${ }^{52}$. It should be noted, however, that the decrease in the proportion of household heads among elderly persons manifested itself in this group in a relatively steady increase in the share of both relatives and lodgers. Although a share of the ageing members of the latter group might have been made up of men who had never before performed the function of the household head ${ }^{53}$, it seems that the likelihood of ending up as inmates in the households of non-relatives grew distinctly after the age of 60 , affecting as much as one-fifth of the total number of men over age $63^{54}$.

In the group of women, the contrasts between the regions are more pronounced. First, the headship rate among older women in the WEST cluster was more than two times lower than in the eastern regions. The percentage of female heads visibly decreased there after they turned 45, and, at around the age of 60, the process decidedly gained strength (not tabulated). In the 58-62 and the 63-67 age groups, the population of women divides into three numerically comparable categories: while the population was still dominated by heads (around 36\%), the rest of the women were spread evenly among relatives and lodgers $(31 \%$ in both cases). The headship rate fell drastically among the oldest women (aged 68 and older), which was accompanied by a proportional increase in the share of women among relatives. However, the flexibility of the family system in terms of incorporating older women into family communities was strictly limited in the western regions. The total averages for both of the oldest age groups (the 63+ age group; see figure 7) indicate that, for nearly one-third of elderly females, residing in households of non-related persons was the only option ${ }^{55}$.

\footnotetext{
${ }^{52}$ Cf. Kopczyński, Studia nad rodzina, p. 150-151.

${ }^{53}$ Szołtysek, 'Three kinds', p. 21, 25

${ }^{54}$ In the age grouping of 23-57 the percentage of lodgers among men remained on the level of about $10 \%$.

${ }^{55}$ Life in rented accommodation as lodgers affected usually the female population, certainly to a greater extent than it did the male. In 63 out 71 parishes of the western cluster (89\%), women among the lodging population were more numerously represented than men. On average, among lodgers in the entire WEST grouping, for 100 women there were only 65 men.
} 
In the eastern regions, the numbers of both men and women residing in the households of non-related persons were marginal (although among women in the EAST 1 cluster, it occurred more frequently). To some degree, this was probably the result of the manor's policy aimed at populating free lands with population surpluses from existent peasant households. The inventories of noble estates from the Lithuanian-Belarusian regions of the $17^{\text {th }}$ and 18 th century mention the practice of filling up individual land allotments, not only with the adult sons of excessively extended households, but also with the so-called bobyle (the equivalents of western lodgers). Most likely, however, these actions mostly involved the younger generations $^{56}$. The key to the distinctness of the eastern territories should surely be sought elsewhere. What is striking is that, that among women in the eastern regions, social senility, though it occurred much earlier than among men, was still considerably postponed in comparison to western regions. This phenomenon appears to be related to the greater share of single women in the group of household heads in the Belarusian and Ukrainian territories ${ }^{57}$. If, then, the family system in these areas provided widowed, aged women with the opportunity to manage a household (even if only nominally), it might be assumed that it generated more favourable conditions for the integration of widowed mothers or widows of co-residing brothers into the structures of complex residential communities centred around biological families and wider kinship circles ${ }^{58}$.

Determining the degree of the social and family isolation of lodgers, as well as the actual position they occupied within the network of social relations of the households they inhabited, is practically impossible exclusively on the basis of a census microdata analysis.

\footnotetext{
${ }^{56}$ Szołtysek and Zuber-Goldstein, 'Historical family systems'.

${ }^{57}$ In central Minsk province (region 11N), in Polessia (11S) and the Zytomierski district (10), the percentage of households managed by women was on average twice as high as in the western cluster $(7.8 \%, 9.4 \%$ and $8.3 \%$ respectively, against $4.3 \%$ in the WEST grouping).

${ }_{58}$ Cf. Obrebski's observations, Polesie, pp. 154-158, in which, on the basis of Belarusian ethnographical material, he points to an increase in the importance of the woman's position with the progression of her age, and among older household heads, to gaining actual equality in the spouses' positions.
} 
Despite suggestions made in the literature about the conflicting character of co-residence with relatives $^{59}$, there were large differences in the quality of life of persons living as inmates in households belonging to non-related persons, and of those co-residing with kin ${ }^{60}$.

Some idea of what this situation meant in practice is provided by the estimates of proportions of elderly people with no spouses, offspring, or any related persons in the residential units they occupied ${ }^{61}$. The share of elderly men living alone was $8 \%$ in the western regions, $2.6 \%$ in the EAST 1 cluster, and just $1 \%$ in the Polessian EAST 3 cluster. The results of the same calculations for the female populations are substantially wider in range: $21 \%$ of all older women in the WEST cluster lived in homes with no immediate or more distant relatives, whereas in the eastern regions, this percentage dropped to $6 \%$ in the transitional zone (EAST 1) and to less than $2 \%$ in Belarusian Polessia ${ }^{62}$.

In order to investigate these issues in more detail, the population of older people in the three regions were grouped according to their marital status, position occupied in the household, and the type of interpersonal relations generated by the condition of co-residence. This time, the focus was exclusively on the female population (Table 4$)^{63}$.

\footnotetext{
59 Rebel, 'Peasant Stem Families'; David Gaunt, 'The Property and Kin Relations of Retired Farmers in Northern and Central Europe', in Wall and Robin (eds.), Family forms, pp. 249-279.

${ }^{60}$ In peasant perception, lodging as subtenants in the houses of other people was often associated with a stark deterioration of the quality of life; see peasant testimonies in various village court rolls, e.g. S. Płaza (ed.), Księga sądowa wsi Iwkowej, 1581-1809 (Wrocław, 1969), entry no. 708, and A.Vetulani (ed.), Księga sądowa Uszwi dla wsi Zawady 1619-1788 (Wrocław, 1957), entry no. 214. That lodging did not necessarily have to mean an advanced social degradation and that the representatives of this group frequently found prospects of promotion, sometimes even taking over the management of a household, was demonstrated on the example of Upper Silesian materials; see: Mikołaj Szołtysek, 'Od makromodeli do mikrohistorii: gospodarstwo domowe w parafii bujakowskiej w latach 1766-1803’, Przeszłość Demograficzna Polski, 25 (2004), p. 35, 39.

${ }^{61}$ Cf. Richard Wall, 'Characteristics of European family and household systems', Historical Social Research 23:1-2 (1998), pp. 44-66.

${ }^{62}$ Of course, isolation or residential distance do not mean lack of contact or interpersonal relations and influences. A classic work on the sociology of the family dealing with this issue is Eugene Litwak, 'Occupational Mobility and Extended Family Cohesion', American Sociological Review, 25:1 (1960), pp. 9-21.

${ }^{63}$ In order to ensure a possibly widest numerical base for the calculations in table 4 the age category of „,60+” was used. In consequence, some of the results listed here are not entirely congruent with values given in previous paragraphs (more restrictive criteria of parish selection for calculations for table 4 also played a part here). Data from the second and fourth panel of the table should be approached tentatively owing to a very small numbers involved in calculation of the figures.
} 
Among elderly household heads in the western areas, marital status determined to a large extent women's residential options. Nearly $70 \%$ of married heads co-resided with at least one person from their immediate family (apart from their spouses), but usually these were unmarried children ( $43 \%$ of elderly women were in this category). In one-fifth of cases, a female household head's family circle included her married children, and sometimes also their single offspring. Less than $10 \%$ of the entire population of older women investigated here lived in this arrangement, however. The situations of female households heads residing only with their spouses (22\%) might have been more complicated, although they still depended to a large extent on extra-familial variables, which cannot be studied using our sources. Among heads without spouses (panel 3 of table 4), two tendencies in particular stand out. On the one hand, the familial environment of these women was narrowed down almost exclusively to their unmarried children, while, on the other, some of them were forced to live entirely on their own ${ }^{64}$. The negative influence of widowhood on residential options was much more pronounced among the group of women who were not household heads (panels 2 and 4). Half of married women from this group lived in the households of the younger generations, most likely in some sort of contractual retirement arrangement ${ }^{65}$. An equivalent group consisted of women residing in households of non-related persons, and their familial circle was usually limited to their spouses. In the group of unmarried women (most frequently widows), a marked transition towards the prevalence of residing in households of non-related persons took place. In western areas, over $90 \%$ of all women in this category lived with nonrelated persons. Women without spouses were in a losing position with regards to access to familial sources of residential support. Their widowhood meant, then, a double deprivation:

\footnotetext{
${ }^{64}$ Farmsteads headed by women were also usually smaller, less equipped in labour force, and thus more exposed to the plight of poverty and even disintegration; Szołtysek, 'Female headship'.

${ }^{65}$ Whether the material circumstance of these women (and their husbands) was in this case regulated by leavetaking contract - as it was often solved in Silesia - remains beyond the scope of our knowledge; their fate, however, might have been relatively stable. Cf. Josef Ehmer, 'House and the Stem Family in Austria', in A. Fauve-Chamoux and E. Ochiai (eds.), The Stem Family in Eurasian Perspective (Bern, 2009), 46-64.
} 
the loss of support from the spouse, and the thinning of prospects for membership in a kinship residential community.

A glance at the data from eastern regions reveal a number of large differences in the situations of older women living there relative to those of women living in the regions discussed above, but the thread of reasoning here must be more tentative because of the very low numbers of some of the populations. Women in four categories represented in table 4 were most likely to co-reside with immediate family members or more distant kin. The familial environment of over a half of married female household heads included married offspring, and sometimes also unmarried children. Both in Polessia and in the transitional zone (EAST 1), the empty nest stage was a rarity, as was shown in earlier observations. Among women who were not the wives of the household heads (panel 2), the tendency to coreside with relatives appears to have been greater than in than in western regions, although it is not possible to be certain of this given the available numerical material. More credence might be given to the results of analyses of co-residence patterns of husbandless women. In this group, the differences between the nuclear family system of the West and the two complex systems from eastern Poland-Lithuania are particularly obvious. Single elderly household heads in the eastern regions usually managed households which included at least one marital unit recruited from offspring (in Polessian communities, nearly three-quarters of female household heads lived in these arrangements). Relative to their counterparts in western areas, the elderly single women who were not household heads in the east resided with relatives four (EAST 1) to eight (EAST 3) times more frequently.

\section{Conclusions}

Studies on the geography of historical family forms in Europe have long been accompanied by the assertion of the existence of drastically different models of the organisation of family 
life on the continent. For a long time, the internal characteristics of these models were approached mostly through categories regarding the structure of households, ignoring the fact that the differences in the composition of residential communities concealed fundamental distinctions in the more general dynamics of everyday family life, as well as in intergenerational relations, family strategies, and even economic mentalities ${ }^{66}$. Within a geographic space, these differences made symptomatic appearances as one moved from the north-western part of Europe to the eastern peripheries of the continent.

Our analysis of material from Polish-Lithuanian lands confirms the basic theoretical dimensions of these hypotheses, although it also suggests the need for a significant revision of the geo-spatial component of these propositions ${ }^{67}$. East-Central Europe of the late 18th century had an "East" and a "West" of its own, and the qualitative and spatial diversification of family models in the Polish, Lithuanian, and Ukrainian lands translated into structural differences in the quality of life of entire families and of individuals. The material studied here reveals that differences in terms of household structure were also indicative of significant differences in the forms of organisation and the composition of the labour force at the level of residential groups, although these were mostly qualitative, not quantitative, disparities. What ultimately distinguishes the family systems compared here is the extent to which co-residing relatives from outside the biological family and non-related persons employed by the family were engaged in the domestic economy. Furthermore, the findings of the present study distinctly suggest that multiple-family households from the eastern regions of historical Poland-Lithuania provided a considerably greater level of protection, especially with regards

\footnotetext{
${ }^{66}$ Lately: Richard M. Smith, 'Social institutions and demographic regimes in non-industrial societies: a comparative approach', in H. Macbeth and D. Collinson (eds.), Human Population Dynamics (Cambridge, 2002), pp. 112-131; Hartman, The household; Gilles Duranton et.al., 'Family Types and the Persistence of Regional Disparities in Europe', Economic Geography, 85:1 (2009), pp. 23-47.

${ }^{67}$ Also Szołtysek, 'Three kinds', pp. 26-28; Szołtysek, 'Rethinking Eastern Europe ‘, pp. 415-417; Szołtysek, 'Life cycle service', p. 82.
} 
to the elderly. The residential isolation of elderly people was a virtually unknown phenomenon in these areas.

Despite the obvious limitations of a study based on census-like microdata in which the household, and not the entire network of social relations occurring beyond its walls, remains the core object of analysis, the results presented here constitute both an invitation to and a convenient starting point for more in-depth and interdisciplinary research into the realities of family life and family strategies for survival in the pre-industrial era. 
MAPS, TABLES AND FIGURES

Map 1: Spatial distribution of the Polish-Lithuanian data (region-level)

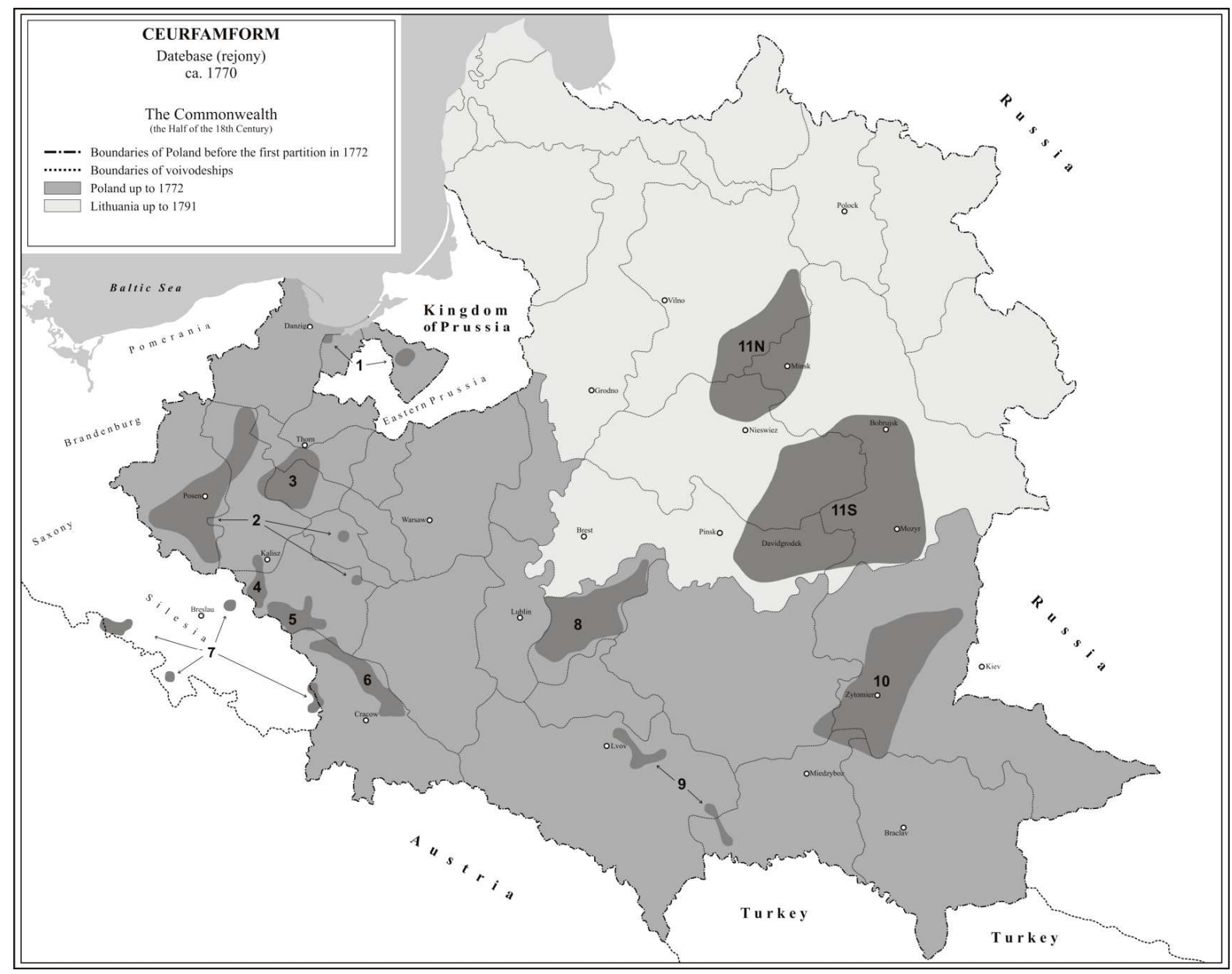

Map drawn up by M. Szołtysek and J. Suproniuk. 
Map 2: Spatial distribution of the Polish-Lithuanian data (region- and cluster-levels combined)

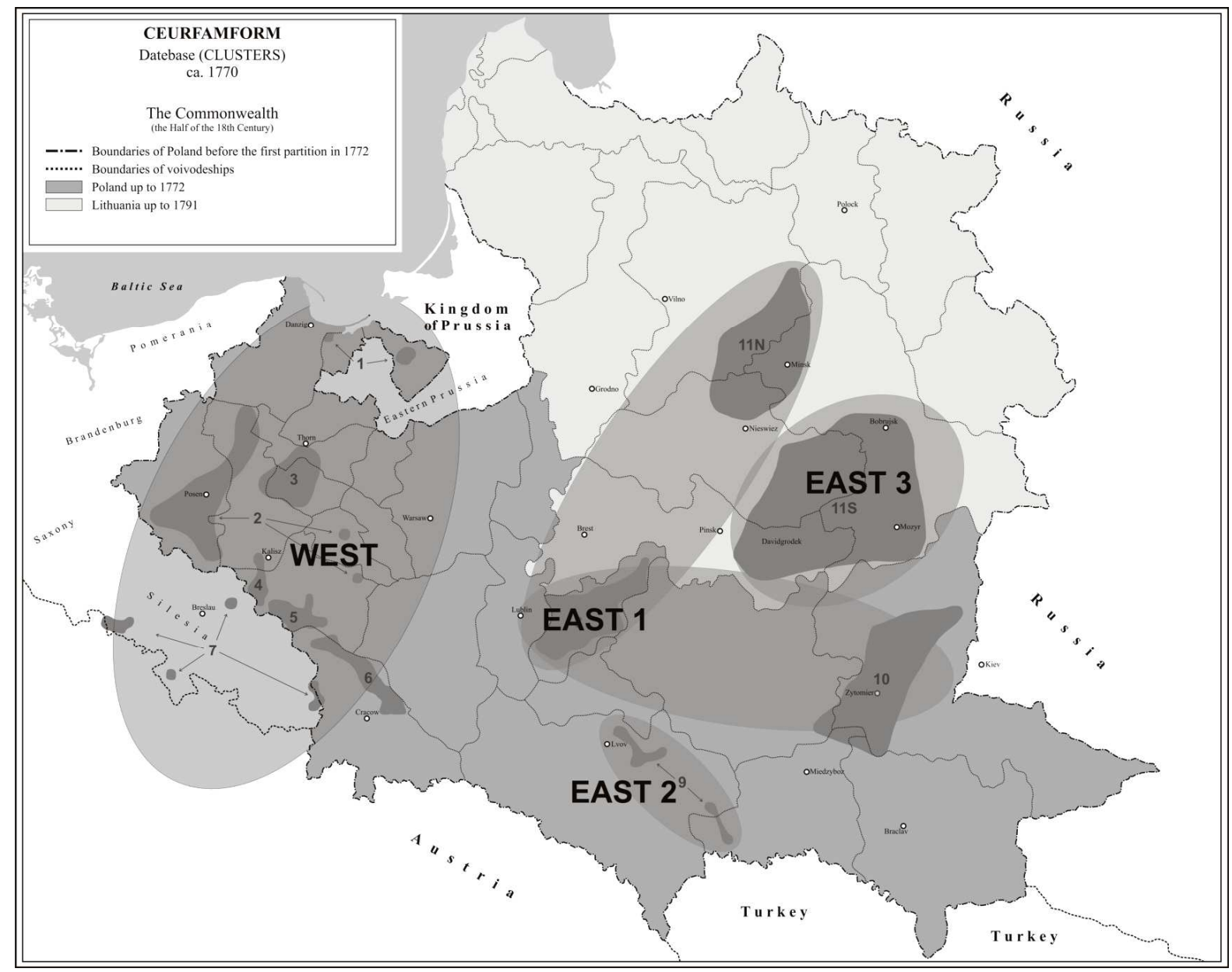

Map drawn up by M. Szołtysek and J. Suproniuk. 
Table 1: Summary characteristics of household composition: Polish and eastern clusters in the late eighteenth century

\begin{tabular}{|c|c|c|c|c|}
\hline \multirow{2}{*}{ Characteristics } & \multicolumn{4}{|c|}{ Cluster } \\
\hline & WEST & EAST 1 & EAST 2 & EAST 3 \\
\hline Total number of households & 11.638 & 10.002 & 1.131 & 3.884 \\
\hline Total population & 66.571 & 58.404 & 5.526 & 25.333 \\
\hline Mean household size & $\begin{array}{c}5.32 \\
(5.36)\end{array}$ & $\begin{array}{c}5.60 \\
(5.78)\end{array}$ & $\begin{array}{c}4.72 \\
(4.72)\end{array}$ & $\begin{array}{c}6.42 \\
(6.58)\end{array}$ \\
\hline Mean house ful size & $\begin{array}{c}5.99 \\
(6.03)\end{array}$ & $\begin{array}{c}5.85 \\
(6.02)\end{array}$ & $\begin{array}{c}5.02 \\
(5.02)\end{array}$ & $\begin{array}{c}6.51 \\
(6.69)\end{array}$ \\
\hline$\%$ nuclear households & 78,72 & 50,97 & 71,68 & 33,56 \\
\hline $\begin{array}{l}\% \text { complex households (types } 4 \text { and } 5 \\
\text { according to Hammel-Laslett scheme) }\end{array}$ & 19,53 & 47,77 & 24,01 & 65,87 \\
\hline $\begin{array}{l}\text { Mean number of conjugal-family units } \\
\text { (CFU) per household }\end{array}$ & 1,13 & 1,51 & 1,18 & 2,06 \\
\hline$\%$ households with two and more CFUs & 10,16 & 31,36 & 12,91 & 54,79 \\
\hline Mean number of offspring per household & $\begin{array}{c}2.26 \\
(2.31)\end{array}$ & $\begin{array}{c}2.41 \\
(2.52)\end{array}$ & $\begin{array}{c}2.25 \\
(2.25)\end{array}$ & $\begin{array}{c}2.34 \\
(2.51)\end{array}$ \\
\hline $\begin{array}{l}\text { Mean number of co-resident kin (other } \\
\text { than spouses and children) per household }\end{array}$ & 0,36 & 1,20 & 0,50 & 2,24 \\
\hline$\%$ households with co-resident kin & 20,53 & 47,20 & 23,75 & 66,61 \\
\hline$\%$ co-resident kin within total population & 5,27 & 21,94 & 11,35 & 32,73 \\
\hline Mean number of servants per household & 0,78 & 0,11 & 0,15 & 0,02 \\
\hline$\%$ households with servants & 38,93 & 9,31 & 12,64 & 1,69 \\
\hline$\%$ servants within total population & 12,37 & 1,86 & 2,44 & 0,23 \\
\hline Mean number of lodgers per household & 0,63 & 0,20 & 0,36 & 0,09 \\
\hline$\%$ households with lodgers & 24,04 & 7,41 & 14,52 & 2,96 \\
\hline$\%$ lodgers within total population & 11,45 & 3,66 & 4,53 & 1,30 \\
\hline
\end{tabular}

Source: M. Szołtysek, CEURFAMFORM Database. 
Notes: Household encompasses members of core families, their coresident kin together with servants attached to the household, but excludes inmates. See Eugene A. Hammel and Peter Laslett, 'Comparing household structure over time and between cultures', Comparative Studies in Society and History, 16 (1974), pp. 86-90).

Values in brackets refer to estimates adjusted after the exclusion of parishes with suspected underregistration of population aged 0-14.

Houseful comprises all individuals occupying separate residential units (not only of the head's core family, but also of his immediate and more distant relatives, as well as coresident servants and inmates or lodgers). See Hammel and Laslett, 'Comparing household', pp. 86-90.

Conjugal-family units are composed of married couples (with or without children), as well as single parents of both sexes with at least one child. See Hammel and Laslett, 'Comparing household', pp. 86-90.

Figure 1: Family and household dependency ratios by age of household head: the Polish regional populations in the late eighteenth century (male household heads 18+ only)

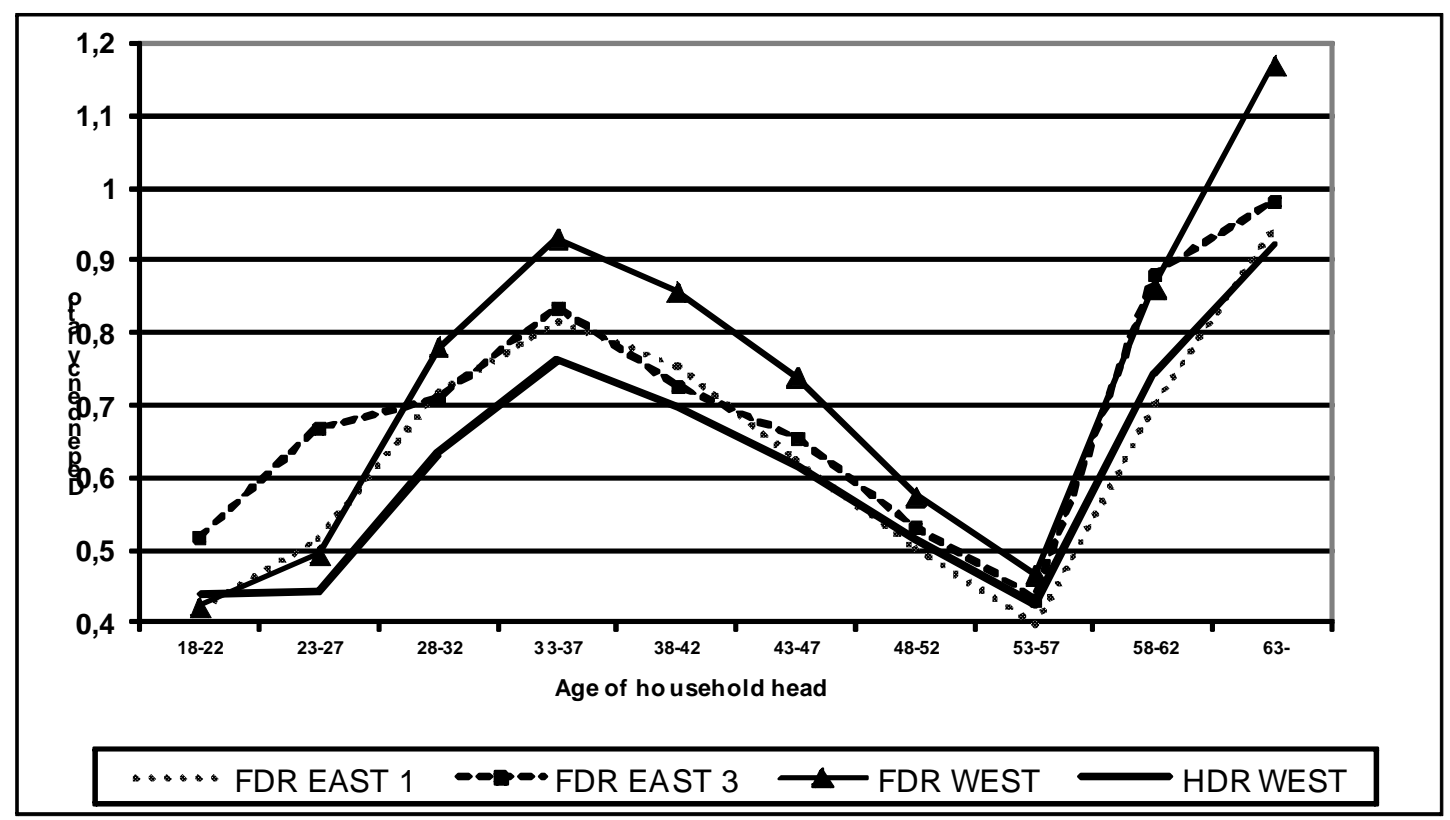

Source: M. Szołtysek, CEURFAMFORM Database.

Notes: FDR (family dependency ratio): the number of population aged 0-12 and 60 and over, per one person in the economically active age range (13-59), at the family level (head's conjugal family + coresiding kin; servants and lodgers excluded). In the 'east' there was no difference in value of FDR against HDR.

HDR (household dependency ratio): the number of population aged 0-12 and 60 and over, per one person in the economically active age range (13-59), at the household level (head's conjugal family + coresiding kin + servants; lodgers excluded).

Based on data for 69 parishes from the 'west' (17 excluded), 75 from EAST 1 (15 excluded), and 50 from EAST 3 (3 excluded). The EAST 2 cluster was not included in the calculation due to small number of cases. 
Figure 2: Consumer/producer ratios by age of household head: the Polish regional populations in the late eighteenth century (married male household heads 18+ only)

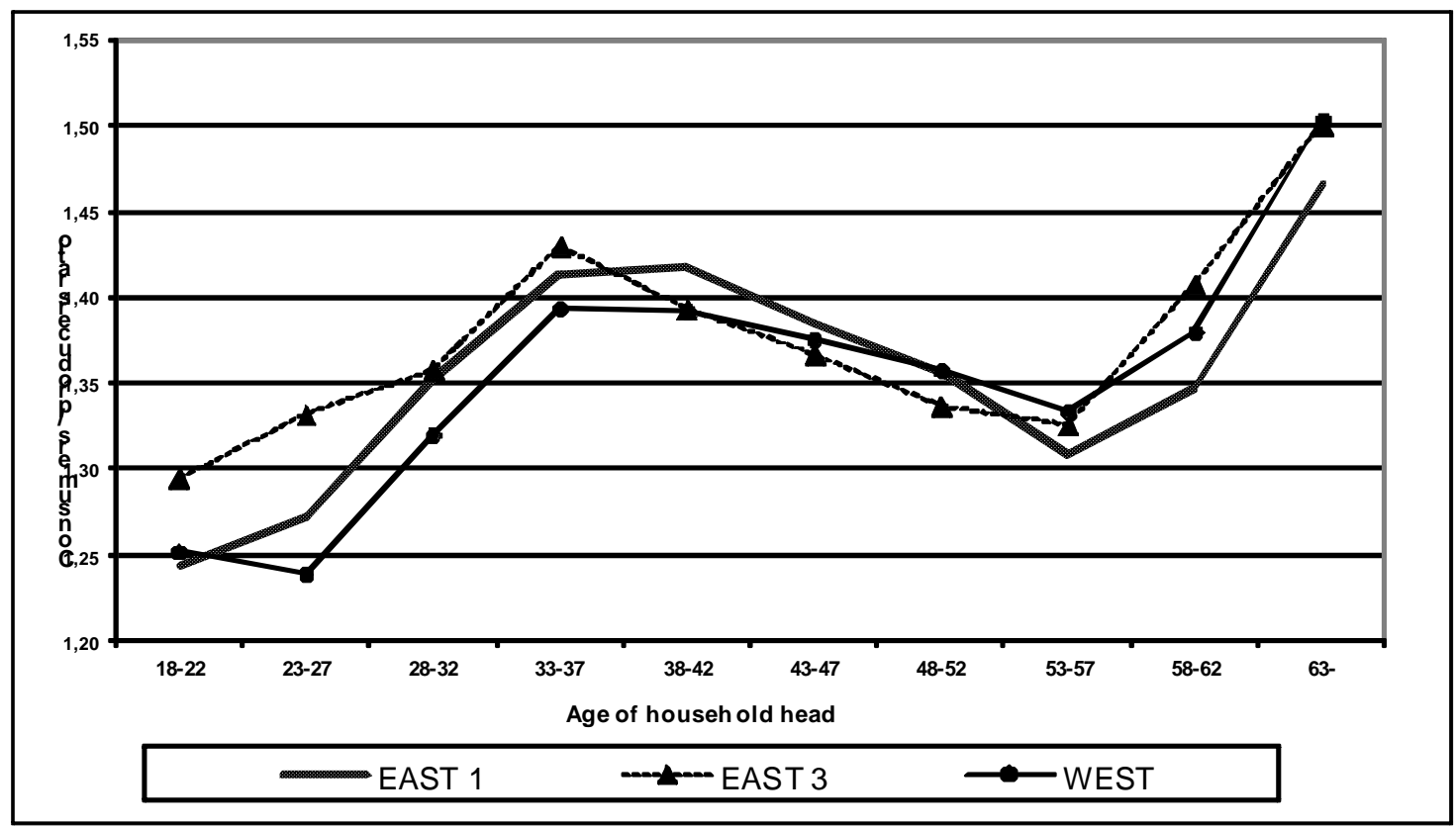

Source: M. Szołtysek, CEURFAMFORM Database.

Notes: The following categories of domestic group members were included in the computation of the c/p ratios: head's conjugal family, other coresiding kin, as well as servants. Non-related lodgers were considered representing separate production-consumption units, and were excluded from calculations.

Inclusion rules of parishes the same as in Figure 1.

Table 2: Demographic dependency ratios by type of household structure and presence of servants - the Polish regional populations in the late eighteenth century (male household heads 18+ only)

\begin{tabular}{|l|c|c|c|c|c|c|}
\hline \multirow{2}{*}{$\begin{array}{c}\text { Household } \\
\text { structure }\end{array}$} & \multicolumn{2}{|c|}{ WEST } & \multicolumn{2}{c|}{ EAST1 } \\
\cline { 2 - 7 } & $\begin{array}{c}\text { Without servants } \\
\text { (FDR) }\end{array}$ & $\begin{array}{c}\text { With servants } \\
\text { (HDR) }\end{array}$ & $\begin{array}{c}\text { Without } \\
\text { servants (FDR) }\end{array}$ & $\begin{array}{c}\text { With servants } \\
\text { (HDR) }\end{array}$ & $\begin{array}{c}\text { Without servants } \\
\text { (FDR) }\end{array}$ & $\begin{array}{c}\text { With servants } \\
\text { (HDR) }\end{array}$ \\
\hline $\begin{array}{l}\text { Simple (Laslett } \\
\text { 3a-3d) }\end{array}$ & $\mathbf{0 , 7 7}$ & $\mathbf{0 , 6 5}$ & $\mathbf{0 , 7 8}$ & $\mathbf{0 , 7 6}$ & $\mathbf{0 , 9 2}$ & $\mathbf{0 , 9 2}$ \\
\hline $\begin{array}{l}\text { Extended (Laslett } \\
\text { 4a-4d) }\end{array}$ & $\mathbf{0 , 8 4}$ & $\mathbf{0 , 6 6}$ & $\mathbf{0 , 7 3}$ & $\mathbf{0 , 7 1}$ & $\mathbf{0 , 7 9}$ & $\mathbf{0 , 7 9}$ \\
\hline $\begin{array}{l}\text { Multiple-family } \\
\text { (Laslett 5a-5f) }\end{array}$ & $\mathbf{0 , 7 6}$ & $\mathbf{0 , 6 4}$ & $\mathbf{0 , 6 8}$ & $\mathbf{0 , 6 7}$ & $\mathbf{0 , 7 2}$ & $\mathbf{0 , 7 2}$ \\
\hline
\end{tabular}

Source: M. Szołtysek, CEURFAMFORM Database.

Notes: Demographic dependency ratios defined as in Figure 1. Inclusion rules of parishes the same as in Figure 1 . 
Table 3: Size distribution of 'male work groups': the Polish regional populations in the late eighteenth century (male household heads 18+ only)

\begin{tabular}{|c|c|c|c|c|c|c|c|c|c|c|}
\hline \multirow{2}{*}{ Region } & \multirow{2}{*}{$\begin{array}{c}\text { Total male } \\
\text { labour force } \\
\text { (freq.=100\%) }\end{array}$} & \multicolumn{8}{|c|}{ \% households with male work group that sizes (in persons): } & \multirow{2}{*}{$\begin{array}{l}\text { Mean size of the } \\
\text { male work group } \\
\text { per household }\end{array}$} \\
\hline & & 1 & 2 & 3 & 4 & 5 & 6 & 7 & $8+$ & \\
\hline WEST & 13.484 & 45,76 & 31,70 & 14,62 & 5,42 & 1,66 & 0,63 & 0,13 & 0,08 & 1,73 \\
\hline EAST1 & 14.596 & 43,75 & 37,43 & 14,26 & 3,69 & 0,72 & 0,11 & 0,04 & 0,01 & 1,75 \\
\hline EAST3 & 7.085 & 34,90 & 39,47 & 18,16 & 5,63 & 1,45 & 0,33 & 0,03 & 0,03 & 1,97 \\
\hline
\end{tabular}

Source: M. Szołtysek, CEURFAMFORM Database.

Notes: 'Male work group' defined as males aged 14-60 in the household. Lodger/inmate population excluded as not belonging to the core households.

Based on data for 69 parishes from the 'west' (17 excluded), 82 from EAST 1 (8 excluded), and 52 from EAST 3 (1 excluded). The EAST 2 cluster was not included in the calculation due to small number of cases. 
Figure 3: Distribution of the 'male work groups' by household membership: the Polish regional populations in the late eighteenth century (male household heads 18+ only)

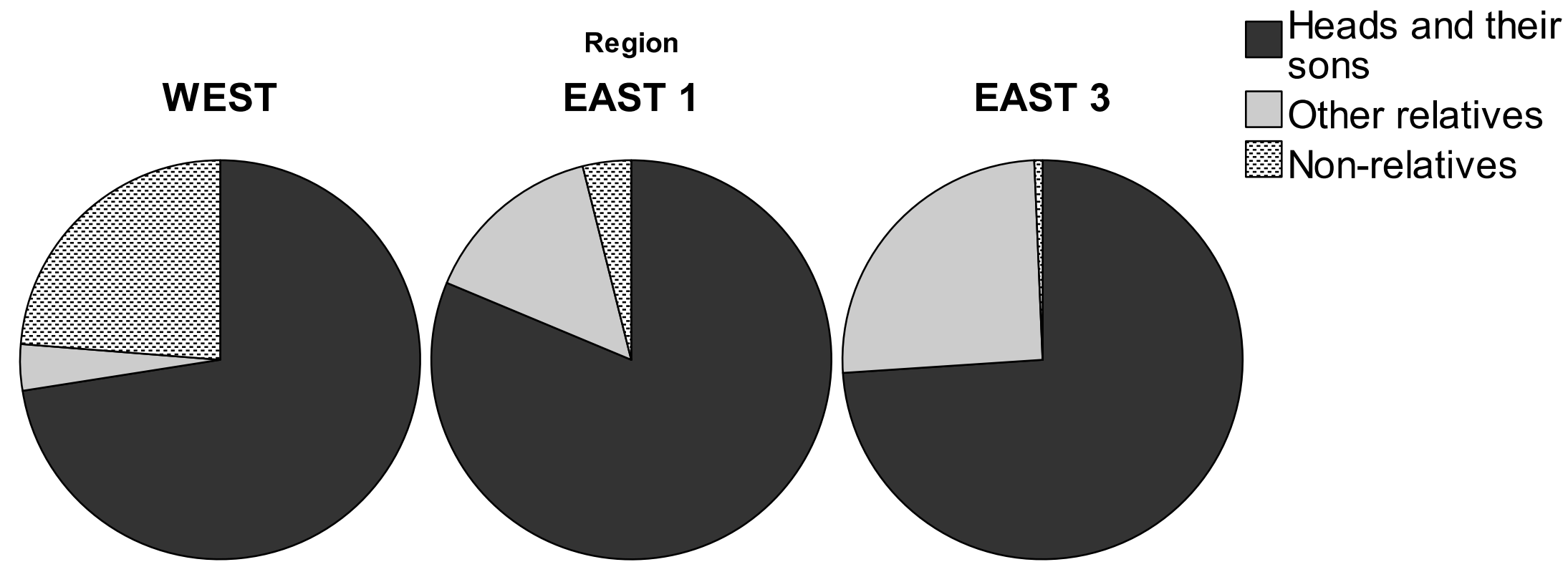

Source: M. Szołtysek, CEURFAMFORM Database.

Notes: Male work group defined as in table 3.

„Other relatives" = all male kin of the head or his wife other than their male offspring, even those registered as 'servants'.

„Non-relatives” = non-related coresident servants.

Inclusion rules of parishes the same as in Table 3. 
Figure 4: Structure of households headed by elderly men (63+): the Polish regional populations in the late eighteenth century

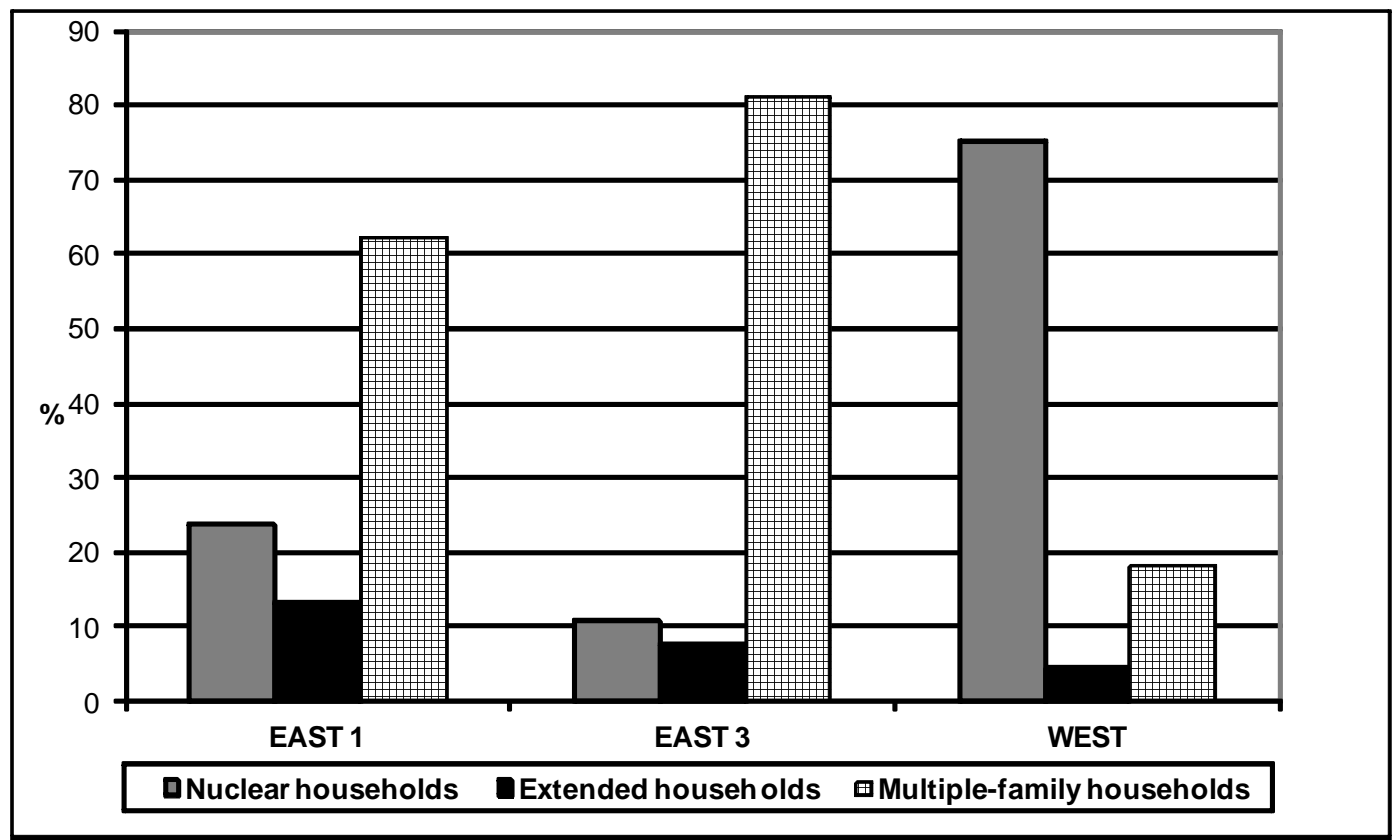

Source: M. Szołtysek, CEURFAMFORM Database.

Notes: Household structure according to Hammel-Laslett scheme.

Based on data for 79 parishes from the 'west' ( 7 excluded), tot. 628 households; 86 parishes from EAST 1 (4 excluded), tot. 962 households; and 53 parishes from EAST 3, tot. 477 households. The EAST 2 cluster was not included in the calculation due to small number of cases.

Figure 5: Structure of households headed by elderly women (63+): the Polish regional populations in the late eighteenth century

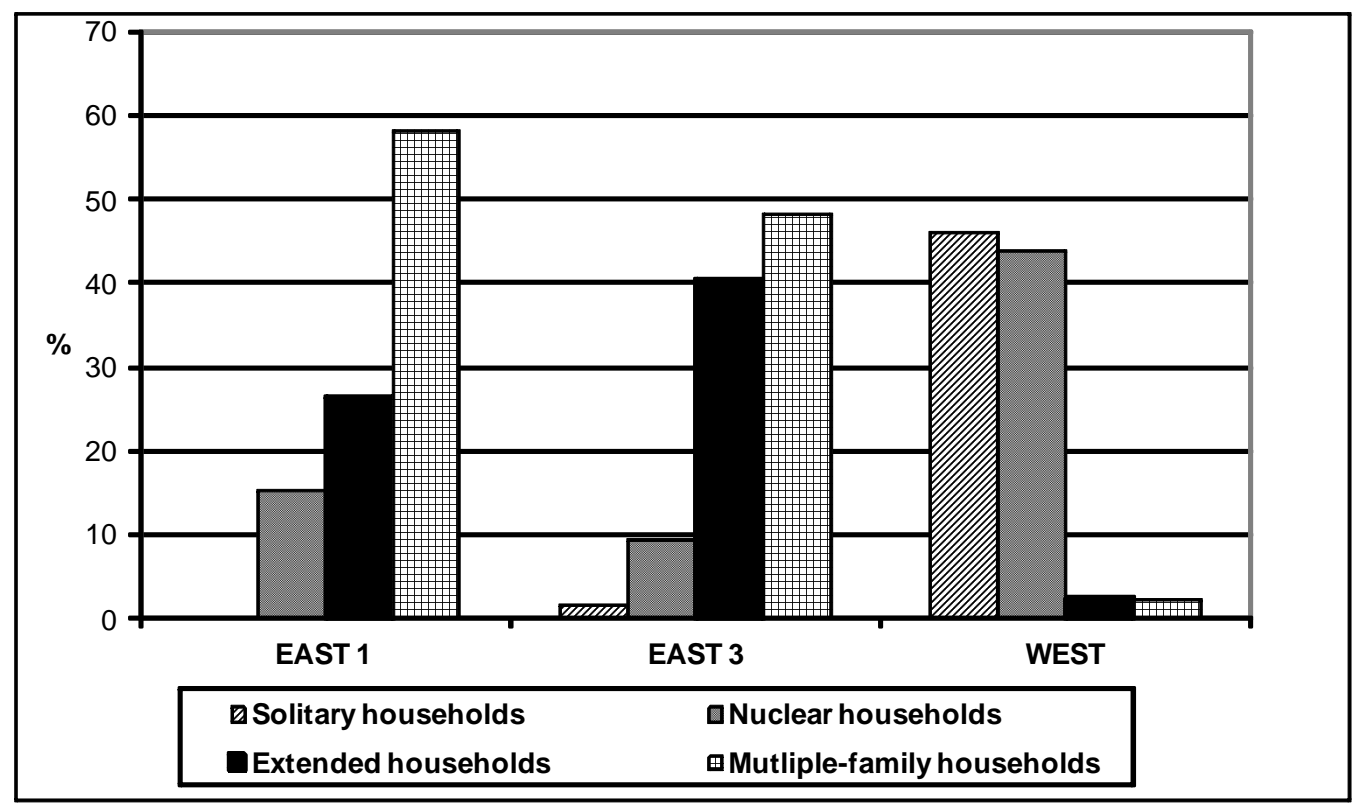

Source: M. Szołtysek, CEURFAMFORM Database.

Notes: Household structure according to Hammel-Laslett scheme.

Based on very small numbers: WEST $=39$ households; EAST 1= 98 households; EAST $3=64$ households. Inclusion rules of parishes the same as in Figure 4. 
Figure 6: Household position of elderly men (63+): the Polish regional populations in the late eighteenth century

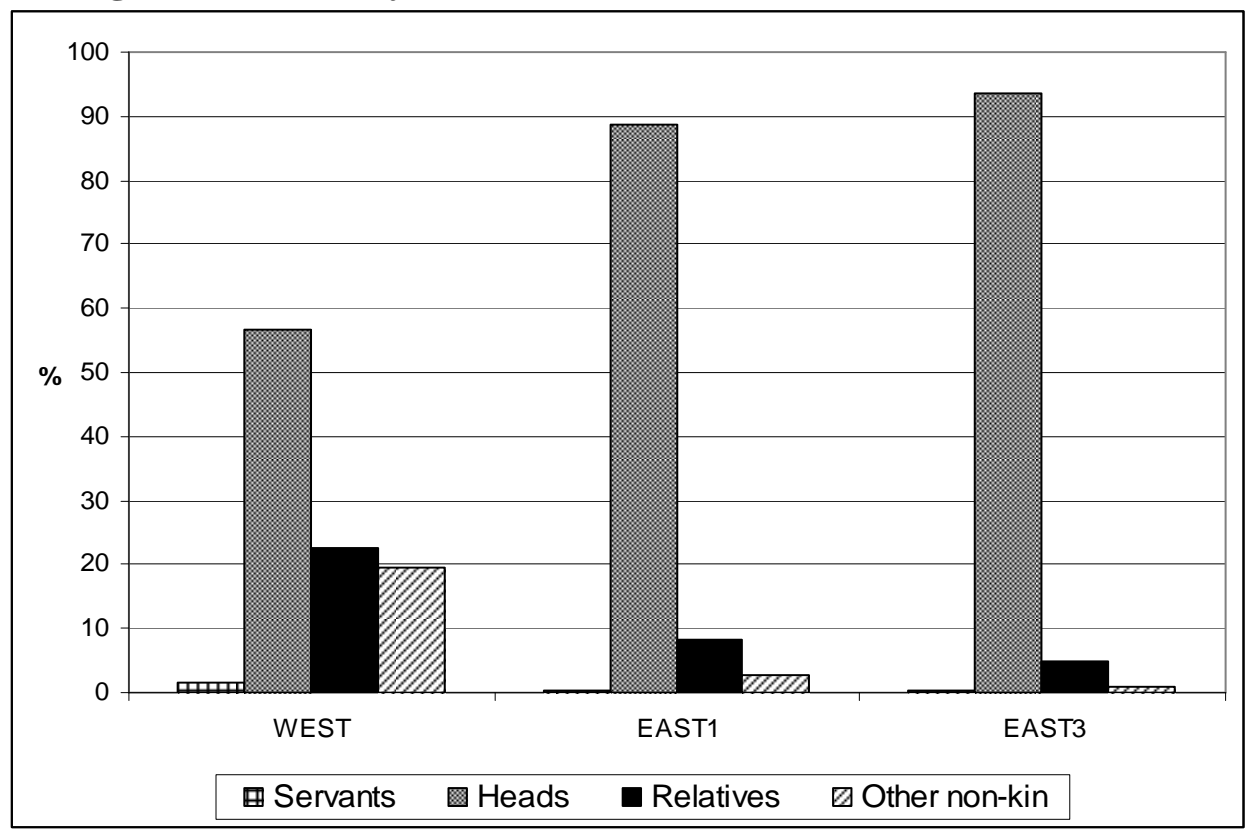

Source: M. Szołtysek, CEURFAMFORM Database.

Notes: "Relatives" are defined as all kin of the head or his wife other than offspring.

„Other non-kin" are defined as all coresident people other than servants who are non-related to the head or his wife.

Based on: WEST $=853$ persons; EAST $1=955$ persons; EAST $3=493$ persons. Inclusion rules of parishes the same as in Figure 1.

Figure 7: Household position of elderly women (63+): the Polish regional populations in the late eighteenth century

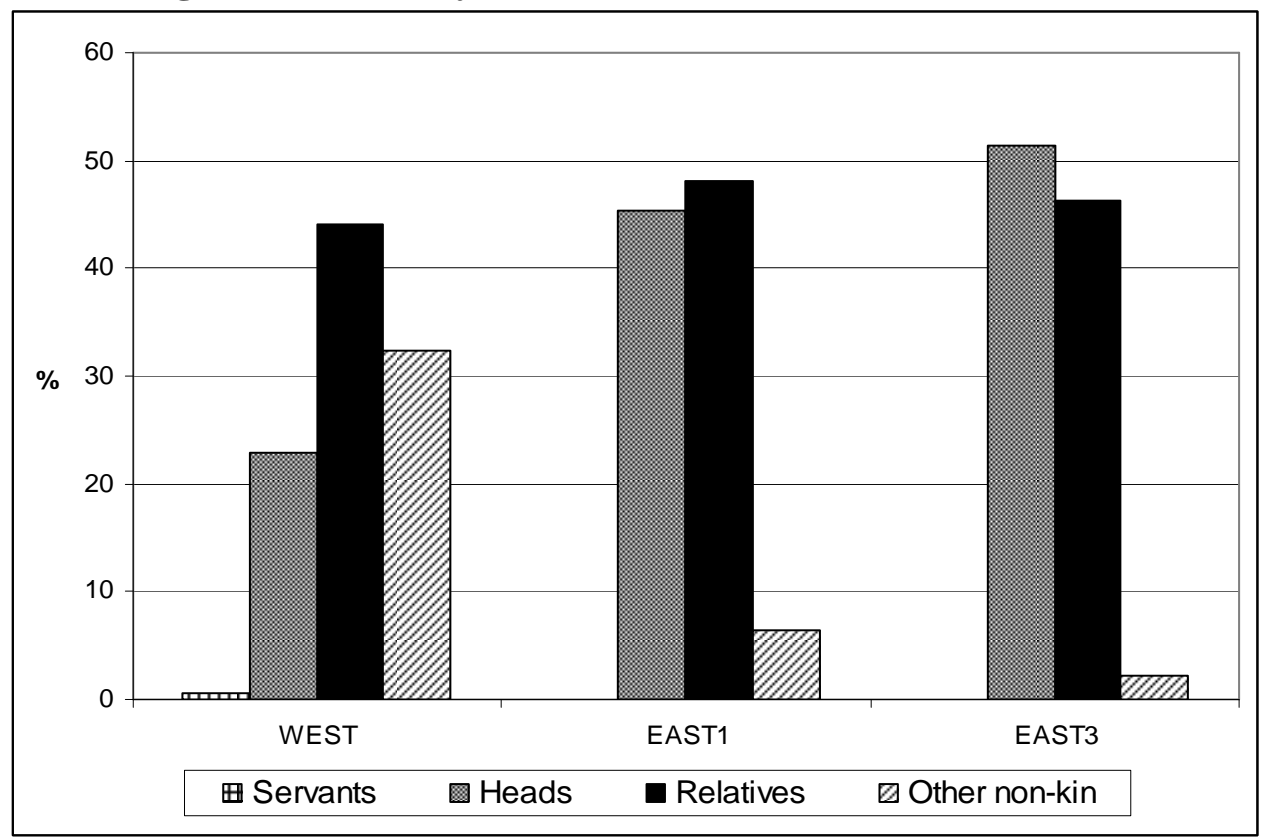

Source: M. Szołtysek, CEURFAMFORM Database.

Notes: definitions and inclusion rules as in Figure 6.

Based on: $\mathrm{WEST}=752$ persons; EAST $1=527$ persons; EAST $3=358$ persons. 
Table 4: Residence patterns of elderly women $(60+)$ by marital status and household position - the Polish regional populations in the late eighteenth century

\begin{tabular}{|c|c|c|c|c|}
\hline $\begin{array}{l}\text { Marital status and } \\
\text { household position }\end{array}$ & Categories of co-residents & EAST1 & EAST3 & WEST \\
\hline \multirow{7}{*}{$\begin{array}{l}\text { Married, household head, } \\
\text { living with: }\end{array}$} & only husband $(\mathrm{H})$ & 1,6 & 1,2 & 21,9 \\
\hline & $(\mathrm{H}+)$ unmarried children & 32,9 & 29,7 & 43,1 \\
\hline & $(\mathrm{H}+)$ married children & 43,1 & 45,1 & 16,1 \\
\hline & $(\mathrm{H}+)$ unmarried and married children & 20,3 & 20,6 & 7,1 \\
\hline & $\begin{array}{l}(\mathrm{H}+) \text { unmarried and married children, } \\
\text { and other relatives }\end{array}$ & 0,5 & 1,6 & 0,0 \\
\hline & $(\mathrm{H}+)$ only other relatives & 0,7 & 1,9 & 1,3 \\
\hline & $(\mathrm{H}+)$ only non-relatives & 0,9 & 0,0 & 10,6 \\
\hline \multicolumn{2}{|c|}{ Overall in this category (freq.) } & $566(=100 \%)$ & $428(=100 \%)$ & $397(=100 \%)$ \\
\hline \multirow{5}{*}{$\begin{array}{l}\text { Married, not household } \\
\text { head, living in the } \\
\text { household of: }\end{array}$} & unmarried children & 0,0 & 0,0 & 1,0 \\
\hline & married children & 50,0 & 13,3 & 49,2 \\
\hline & parents & 0,0 & 6,7 & 0,0 \\
\hline & other relatives & 11,1 & 66,7 & 1,0 \\
\hline & non-relatives & 38,9 & 13,3 & 48,7 \\
\hline \multicolumn{2}{|c|}{ Overall in this category (freq.) } & $18(=100 \%)$ & $15 \quad(=100 \%)$ & $191(=100 \%)$ \\
\hline \multirow{7}{*}{$\begin{array}{l}\text { No spouse present, } \\
\text { household head, living } \\
\text { with: }\end{array}$} & unmarried children & 33,3 & 26,8 & 53,3 \\
\hline & married children & 44,9 & 54,3 & 5,0 \\
\hline & unmarried and married children & 20,4 & 17,7 & 5,0 \\
\hline & $\begin{array}{l}\text { unmarried and married children, and } \\
\text { other relatives }\end{array}$ & 1,4 & 0,6 & 0,0 \\
\hline & only other relatives & 0,0 & 0,0 & 3,3 \\
\hline & only non-relatives & 0,0 & 0,0 & 6,7 \\
\hline & alone & 0,0 & 0,6 & 26,7 \\
\hline \multicolumn{2}{|c|}{ Overall in this category (freq.) } & $294(=100 \%)$ & $164(=100 \%)$ & $60 \quad(=100 \%)$ \\
\hline \multirow{3}{*}{$\begin{array}{l}\text { No spouse present, no } \\
\text { household head, living in } \\
\text { the household of: }\end{array}$} & married children & 0,0 & 0,0 & 0,6 \\
\hline & other relatives & 33,3 & 67,7 & 8,2 \\
\hline & non-relatives & 66,7 & 32,3 & 91,2 \\
\hline \multicolumn{2}{|c|}{ Overall in this category (freq.) } & $75 \quad(=100 \%)$ & $31(=100 \%)$ & $354(=100 \%)$ \\
\hline \multicolumn{2}{|c|}{ Overall in all categories (freq.) } & 953 & 638 & 1002 \\
\hline
\end{tabular}

Source: M. Szołtysek, CEURFAMFORM Database.

Based on data for 70 parishes from the 'west' (16 excluded), 75 from EAST 1 (15 excluded), and 52 from EAST

3 (1 excluded). The EAST 2 cluster was not included in the calculation due to small number of cases. 